\title{
Patricio Antonio López, indio romancista (Romancero vulgar del siglo XVIII novohispano)
}

... Asentándome [los cantares indígenas] el que las lenguas empezasen todas en verso, pues yo vi, así en los rústicos de la Silesia como en los plebeyos de Venecia, que todos nacen con aire de poetas.

BotURINI, Idea, XV, 5.

1. En uno de los artículos de su Biblioteca bispanoamericana septentrional (1816-1821), José Mariano Beristáin de Souza registra la siguiente noticia:

LÓPEZ (DON PATRICIO). Indio noble, cacique, originario del valle de Oaxaca. Erudito y curioso apreciador de las antigüedades de su patria. Tenía una copiosa librería, de que hace mención el ilustrísimo Eguiara en el artículo «F. Antonius ab Ascensione» de su Biblioteca Mexicana, donde insinúa que López escribió muchas cosas. Pero yo sólo he podido hallar el siguiente opúsculo... '

Y cita (o glosa, por mejor decirlo) el título de uno de los romances de López, que puede compendiarse así: Triumphos aclamados contra vandoleros ${ }^{2}$.

1 José Mariano BERISTÁIN DE SoUZA, Biblioteca hispanoamericana septentrional (2. ${ }^{2}$ ed. Amecameca: Tipografía del Colegio Católico, 1883). La mención de Eguiara se produce a propósito de una obra curiosa que poseía don Patricio en 1755 (fecha en que Eguiara comenzó a publicar su libro): «qui extat in Bibliotheca Indi in paucis insignis D. Patricij Lopez, de quo suo loco multa trademus». Juan José de EGUIARA y EGUREN, Bibliotheca Mexicana (México: UNAM, 1986), vol. I, p. 159.

2 El título completo del pliego de López es el siguiente: «Triumphos aclamados contra Vandoleros por la Real Justicia que (a los influjos de el Excelentísimo Señor Don Balthazar Manuel de Zúñiga Guzmán Sotomayor, Sarmiento, y Mendoza: Marqués de Balero, Ayamonte, Alenquer, Virrey Governador, y Capitán General, que fue de esta Nueva España, y Mayordomo Mayor de la Sereníssima Princesa nuestra Señora) a conseguido el Capitán Don Miguel Velazques Lorea, Provincial de la Santa Hermandad, en este Reyno; que con inserción de la Real Cédula de gracias, conque su Magestad (que Dios guarde) le ha honrado. Obsequioso escrive, y reverente consagra al mismo Excelentíssimo Señor la encogida pluma de Don Patricio Antonio López, Cazique Originario del Obispado de Antequera, Valle de Oxaca. Con Licencia de los Superiores en la Puebla de los Ángeles en la Imprenta de la Viuda de Miguel de Ortega, en el Portal de las Flores. Año de 1723.» 
Méndez Plancarte incluye a Patricio López en su antología de Poetas novobispanos (1942), donde reproduce, fragmentariamente, un segundo pliego del poeta indio. El romance relata la comisión de un crimen perpetrado el 13 de julio de 1720. Su extenso título describe, en su inicio, de modo por lo demás curioso, la humilde "poética» del romancista: Breve, claro, llano, simple, narrativo y verdadero romance ${ }^{3}$. Esta es la única pieza de Patricio López asequible en una edición moderna, aunque sólo sea fragmentariamente.

López «fue acaso [en palabras de Méndez Plancarte] el único aborigen que desde Alva Ixtlilxóchitl nos legara versos hispanos, y uno de los raros indígenas declarados que a principios del XVIII ostentaran estudios superiores» ${ }^{4}$. De ahí, quizá, el barroquismo de «sus erudiciones bíblicas y clásicas», pero también el estilo de los romances de López, que Méndez Plancarte formula al decir: "cierto "gongorismo" abaratado por la más divulgada manera de Calderón» 5 .

Pues lo más saliente del estilo de López es su esmaltado popularismo, la peculiar «delectación cultista» que hace esplender el relato de hechos sensacionales. En este sentido, los romances de Patricio López forman parte de una tradición poética que prefigura la vena del «corrido» popular ${ }^{6}$ :

Típico ejemplo de esas métricas «relaciones», espontáneas y «en caliente», de acaecimientos públicos, pero no universitarios ni religiosos ni cortesanos, sino sencillamente «sensacionales», su poema de 1720 parécenos [...] óptimo precursor de nuestros «corridos», por su «crónica roja» (aunque seguida de ejemplar escarmiento), la cálida fluidez y el minucioso realismo, las obvias «filosofías», el instinto romántico

3 Transcribo, también, el título de este otro pliego: «Breve, claro, llano, simple, narrativo, y verdadero romance a la violenta muerte que prodictoriamente executó Don Joseph de Estrada Tuñón, el día 13 de Julio del año de 1720, en el Coronel don Gonzalo Gámez Mesía, Gentil Hombre de la Cámara de su Magestad, y Governador, que fue de la Nueva Vera Cruz. Que entonzes escrivió Don Patricio Antonio Lopes, Cazique Zapoteco de uno de los Valles de Antequera; y dedicó al Corregidor, y Juez, que fue de esta Causa, a cuyo zelo se devió el desagravio de la Justicia. Con la punición del homicida, y degüello que en él se executó en la plaza pública de esta Corte.» El pie de imprenta aparece al fin del pliego: «Con Licencia de los Superiores en la Imprenta de la Viuda de Miguel de Ortega y Bonilla, año de 1724.»

4 Alfonso Méndez Plancarte, Poetas novohispanos (México: UNAM, 1942), vol. 3 , p. LXII. López es uno de los últimos poetas incluidos en la antología.

5 Ibid., p. LXI. Méndez Plancarte comenta los romances de López junto a otro del presbítero Miguel Gutiérrez Godínez: «Romance del glorioso Ladrón San Dimas», editado en Puebla, en 1719 y 1783 , y en México, en 1751.

6 En sus notas al romance de López, Méndez Plancarte añade otro antecedente del corrido: «Subrayaremos, en Sor Juana (Villancicos de la Asunción, 1687, III), aquel rasgo tan curioso como inadvertido por Mendoza, Castañeda, Saldívar, y demás estudiosos del género: Un Corrido es lo mismo que una Jácara». Ibid., p. 211. 
de la hora decorativa y de los contrastes, la cristiana piedad que se extiende al ajusticiado, y hasta la delectación cultista que esmalta su popularismo [...], la puntualidad de las fechas, la invocación de la «tórtola» (que será la posterior «palomita»), y la humildosa despedida final ${ }^{\text {? }}$.

Más que el estilo de Patricio López, lo que describe Méndez Plancarte son ciertos tópicos, fórmulas y rasgos de estilo del romancero vulgar, cuyos avatares indoamericanos me propongo explorar en este trabajo.

Las referencias más completas de los pliegos de López conservados hoy las da el bibliógrafo José Toribio Medina en dos estudios: La imprenta en México (1539-1821) y La imprenta en la Puebla de los Ángeles (16401821). Medina consigna allí el romance citado por Beristáin, pero también un tercer romance del mismo carácter (los Triumphos de otros quarenta vandoleros ${ }^{8}$ ) y otro opúsculo en verso, compuesto en forma de «quintillas vulgares» o «coplas de ciego» ", y titulado sucintamente General aclamación de la lealtad mexicana ${ }^{10}$.

7 Ibid., Pp. LXI-LXII.

8 Transcribo, íntegra, la portada de este pliego de López: «Triumphos que la Real Justicia ha conseguido de otros 40 Vandoleros con los hechos en la vida; y estremos en la muerte, de Manuel Calderas, uno de sus principales Caudillos, condenado con todos sus Compañeros por famosos Grazatores, en la pena de el último suplicio: Por el Capitán Don Miguel Velásquez Lorea, Alguacil Mayor de el Tribunal de la Santa Inquisición, Alcalde Provincial, Juez de la Cordada, de este Reyno, y de el de la Nueva Galicia, confirmada, y aprobada por su Magestad (que Dios guarde) con la succeción de ella en Don Joseph Velásquez su Hijo, y successor. Lleva estampado el horroroso, y férreo Instrumento conque. se haze justicia en los Delinquentes. Lo escrive, y consagra, al Excelentíssimo Señor Marqués de Valero, Vi-Rey Governador, y Capitán General, que fue de este Reyno: y presidente oy de el Real, y Supremo Consejo de Indias: en cuyo feliz govierno, y a cuyo providente acuerdo se debió, el acierto en la Elección de tan importante, y recto Ministro. Don Patricio Antonio López, Cazique de la Nación Zapoteca, en los Valles de Antequera: y uno de los que pretendieron ocupar, interinaria, la plaza de Solicitador, y Agente de negocios de Naturales, con informe que para ello a su favor hizo a su Excelencia en vista de sus cortos méritos: el Señor Marqués de Villahermosa, de Alfaro, del Consejo de su Magestad su Oidor Decano en esta Real Audiencia. Con Licencia: En México por los Herederos de la Viuda de Miguel de Rivera, en el Empedradillo. Año de 1726.»

9 Las «quintillas vulgares» o quintillas dobles fueron, hasta el primer cuarto del siglo XVII, el metro predilecto de los poetas vulgares (de ahí que se les aplicara, restringidamente, el nombre de coplas de ciego). A partir de entonces, «las llamadas coplas de ciego dejaron el campo libre a los romances de ciego»; María Cruz GARCf́a DE ENTERRfA, Sociedad y poesía de cordel en el Barroco (Madrid: Taurus, 1973), p. 146.

10 El título completo de este pliego de López es el siguiente: «General aclamación de la lealtad mexicana: En la más solemne Jura del Luminar más flamante, el Señor 
Patricio López redactó esta pieza con motivo de la jura del rey Luis I, en 1724. Y si, en su género, el poema imita las tradicionales «coplas de ciego», el poeta aprovecha unos versos de Góngora para «esmaltar», eruditamente (con esa erudición del dominio público tan característica de la elocuencia vulgar), la crónica en verso de los festejos. Todo ello, por cierto, sin dejar de afirmar la vena justiciera y plebeya que inspira el conjunto de sus romances:

Mi musa que sin malicia
triumphos de Justicia, y ley
siempre ha cantado propicia,
oy quiere en Jura del Rey
cantar también de Justicia.
$\quad$ Y aunque algunos importunos
no aplaudan, y hagan el fiero,
no quiero aplauso de algunos,
popular aplauso quiero;
perdónenme los Tribunos ${ }^{11}$.

Medina aporta, por último, un dato esencial para la localización de los pliegos. Pertenecientes (como él apunta) a la Biblioteca Andrade, todos ellos se conservan hoy en la Colección Latinoamericana de la Universidad de Austin. Ignoro si se trata de los ejemplares consultados antes por Méndez Plancarte ${ }^{12}$, pero ninguna obra de Patricio López existe en los fondos que he podido re-

Don Luis Primero: que (con incerción de la Carta, o Renuncia, que en su Magestad hizo el Señor Don Phelipe Quinto, su Padre) Leal escribe, y rendido consagra a la mesma Magestad, la más humilde Pluma de Don Patricio Antonio López, Cazique de uno de los Valles de Antequera.» El pie de imprenta aparece al fin del pliego: «Con Licencia en México: Por Juan Francisco de Ortega Bonilla, año de 1724, en la calle de Tacuba.»

11 La estrofa a la que aluden los versos subrayados por López pertenece a un romance de Góngora, «La ciudad de Babilonia», sobre la que se dice que

$$
\begin{aligned}
& \text { digno sujeto será } \\
& \text { de las orejas del vulgo; } \\
& \text { popular aplauso quiero, } \\
& \text { perdónenme sus tribunos. }
\end{aligned}
$$

Luis de GÓNGORA, Romances (Madrid: Cátedra, 1985), pp. 385-386.

12 También Vicente $T$. Mendoza alude al romance parcialmente reproducido por Méndez Plancarte en su «Lista de romances impresos en México durante la época colonial»; Vicente T. MENDOZA, El romance español y el corrido mexicano (México: Universidad Nacional, 1939), p. 784. Pero, aunque reproduce el grabado del pliego en una lámina de su libro, Mendoza no se refiere a ninguno de los romances de López en el cuerpo de la obra. 
visar hasta ahora ${ }^{13}$. Yo poseo fotocopias de esos cuatro pliegos, que forman, junto con el recién descubierto Mercurio Indiano (cuyo manuscrito, en microfilm, me ha permitido consultar la doctora Beatriz Mariscal), el testimonio de lo que pudo ser un romancero vulgar autóctono de la Nueva España, pero también la obra de Patricio López, cronista erudito y romancista popular, poeta indio, intérprete intercultural y cultivador de un género prácticamente ignorado de la tradición novohispana: el «romance de ciego» en su vertiente roja o patibularia.

2. La cuestión del traslado el Romancero a América tiene que ser trazada sobre el horizonte de su contexto sociocultural. Y ese horizonte fue, en primer lugar, el de la violencia que ejerció la Conquista y que el testimonio de los cronistas asocia al universo de los prestigiosos «romances viejos» ${ }^{14}$.

Aparte de los romances tradicionales citados en las crónicas de la Conquista, el romancero «nuevo» y el «historial» (por no hablar de los romances de tradición moderna) se trasladaron pronto a la América española ${ }^{15}$. Al

13 Ninguna obra de Patricio López existe en el Fondo Reservado de la Biblioteca Nacional, en la Biblioteca del Centro de Estudios Históricos de Condumex, en la Biblioteca del Instituto Nacional de Antropología e Historia, en la Biblioteca del Archivo General de la Nación, en la Hemeroteca Nacional, ni tampoco (hasta donde he podido comprobar) en los ramos de Inquisición, de Bandos e Impresos Oficiales, Criminal y de Acordada del mismo Archivo, cuyos volúmenes suelen incluir folletos antiguos encuadernados entre sus folios.

14 Dos cronistas tan diferentes como Bernal Díaz y Bartolomé de las Casas aplican el mismo romance viejo a la figura de Hernán Cortés:
Mira Nero de Tarpeya
a Roma cómo se ardía, gritos dan niños y viejos
y él de nada se dolía.

Sobre este y otros ejemplos de transmisión de romances viejos a México y al Perú (es decir, de los romances impresos y divulgados en colecciones y pliegos sueltos durante la primera mitad el siglo XVI), consúltense las páginas dedicadas al tema en Ramón MENÉNDEZ PIDAL, Romancero hispánico (Madrid: Espasa-Calpe, 1953), vol. II, pp. 226-231.

15 Romances «nuevos» son los que, a imitación de los «viejos» y tradicionales, escribieron los poetas cultos a partir del auge del romancero en la primera mitad del siglo XVI. Los romances «historiales» se limitan a versificar crónicas e historias originalmente redactadas en prosa. He aquí un ejemplo de romance «nuevo» compuesto en México y relativo a la figura del conquistador:

\section{En Tabuca está Cortés con su escuadrón esforzado, triste estaba y muy penoso, triste y con grande cuidado.}

Menéndez PIdAL, op. cit., p. 233. 
menos dos ciclos romancísticos americanos han sido analizados por los especialistas: uno tiene por tema la figura de Cortés y el otro algunos pasajes de La Araucana ${ }^{16}$.

También don Fernando de Alva Ixtlilxóchitl (1568-1648), indio noble e intérprete como don Patricio, escribió romances. Uno de ellos, el Romance del rey don Sancho, se acopla íntegramente con la tradición castellana ${ }^{17}$, sin dejar de recordar, por ello, las elegías de los antiguos príncipes mexicanos:

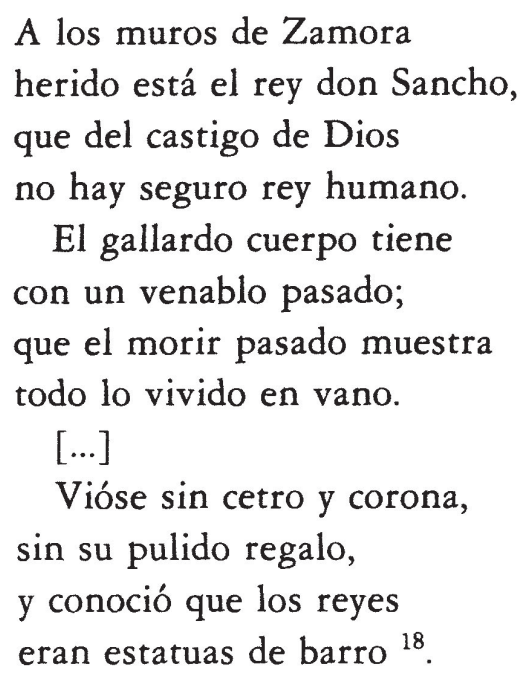

$\mathrm{Su}$ otro romance se inspira, en cambio, en fuentes indígenas. $\mathrm{Y}$ aunque pretende ser la traducción de un cantar de Nezahualcoyotl, es más bien, como apunta Méndez Plancarte, un «mosaico» de poesías aztecas, «muy atenuados sus brillos y audacias, pero con sus metáforas gemáticas y florales y su lento lamento de la vida fugaz» ${ }^{19}$. Allí se congregan los antiguos príncipes en figuras de plumas y piedras preciosas. Allí se lamenta la brevedad de su reino (como en el Romance del rey don Sancho) y la orfandad en que dejan a sus vasallos. Heredero e intérprete de una tradición, el poeta recrea una poesía aristocrática y asume, a la vez, la voz de los vasallos indios, todo ello con lo humildes medios que le presta el traslado (y el mestizaje, ahora) del romance español:

16 Me refiero a los siguientes estudios: José María Cossfo, «Romances sobre La Araucana», Estudios dedicados a Menéndez Pidal (Madrid: CSIC, 1954), vol. 5, pp. 201229. Winston A. RAYNolds, Romancero de Hernán Cortés (Madrid: Alcalá, 1967). El romance citado en la nota anterior forma parte del ciclo estudiado por este último autor.

17 Alva Ixtlilxóchitl imita los romances del ciclo del Cerco de Zamora, que Gónzalez de Eslava contrahizo, también, a lo divino. Alonso Méndez Plancarte, Poetas novobispanos (México: UNAM, 1942), vol. 1, p. 149.

18 Ibid., p. 146.

19 Ibid., pp. XXXVII-XXXVIII. 


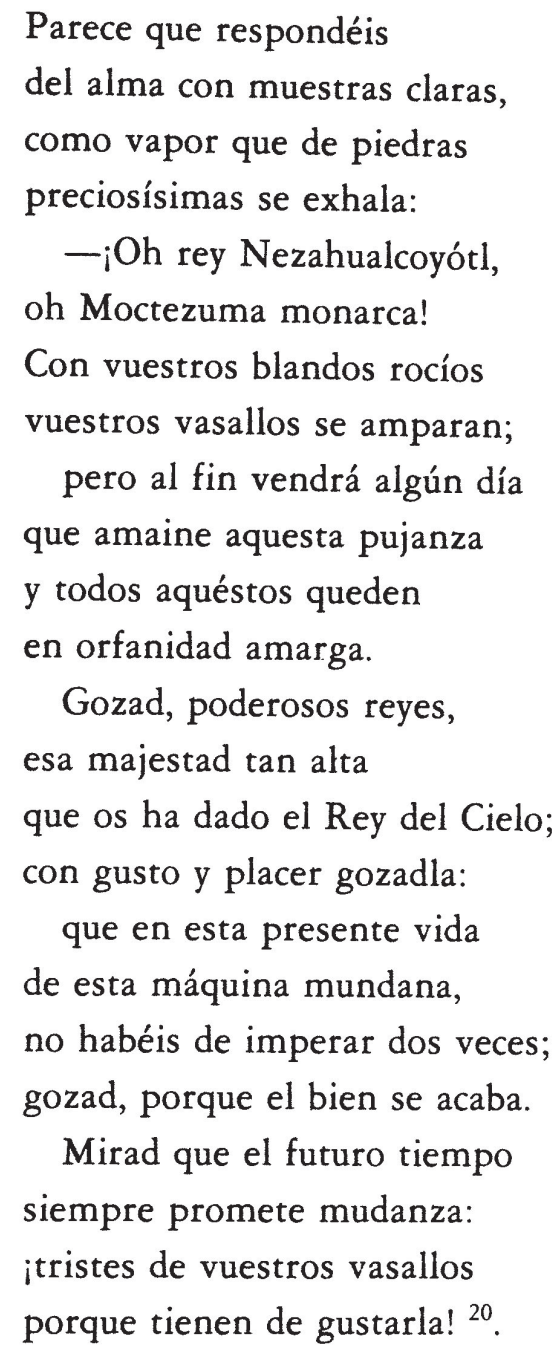

La invención romancística de Alva Ixtlilxóchitl corresponde, en suma, a un segundo traslado del Romancero a América: a su hibridación y a su mestizaje ${ }^{21}$. $\mathrm{Y}$ a esa vertiente pertenecen también nuestros pliegos y el Mercurio Indiano.

Patricio López leyó, sin duda, los romances compuestos por Ixtlilxóchitl ${ }^{22}$. Pero no hay que atribuir a esta circunstancia fortuita la incursión de López en las fronteras del romance mestizo. En su doble calidad de indios nobles e intérpretes del Virreinato, ambos poetas cumplen con dos funciones divergentes y complementarias: la función asignada por la tradi-

20 Ibid., p. 145.

21 Por «mestizaje» e «hibridación» entiendo, no la fusión de dos códigos culturales que producen una expresión o un código nuevos, sino, simplemente, la «mezcla», la yuxtaposición conflictiva de tradiciones separadas aún. Para una crítica del uso de esta nociones (y para la noción de «intérprete intercultural»), véase: Martin LiENHARD, «Mesoamérica. La llamada crónica indígena», Literatura Mexicana, I (1990), pp. 9-21.

22 Sobre este punto, véase infra, n. 67. 
ción indígena a los depositarios de la memoria histórica y de la escritura ${ }^{23}$, y la función asignada por los tribunales a los depositarios de la lengua y el legado indígenas. Ambos son transmisores y divulgadores, a la vez que intérpretes ante la justicia.

3. Este último aspecto de la labor del intérprete (su actuación en los tribunales) me devuelve a los pliegos publicados por López en la segunda década del siglo XVIII. Y si, para el texto del Mercurio Indiano, cabía rastrear una prosapia ilustre en los romances mestizos de Alva Ixtlilxóchitl, también cabe indicar un precursor insigne de esos romances impresos en pliegos sueltos.

La justamente famosa Relación fúnebre de don Luis de Sandoval Zapata (h. 1620-1671) narra, en términos muy apegados a las convenciones del romance vulgar, la «infeliz, trágica muerte» de los hermanos Ávila, «degollados en la nobilísima Ciudad de México a 3 de agosto de 1566», presuntamente a causa de su participación en la conjura política de Martín Cortés ${ }^{24}$. El romance sigue, paso por paso, las ceremonias del juicio y la degollación, intercalando alegatos y protestas jurídicas en las pausas abiertas por el espectáculo ${ }^{25}$. Pero al hacerlo construye, también línea por línea, un segundo ritual o un ritual de segundo grado, compuesto de tópicos y figuras retóricas, de invocaciones, lamentaciones, acusaciones y consolaciones que convergen siempre en la escena trágica reservada al suplicio. La maestría estilística de Sandoval Zapata nos revela esa escena a través de un tamiz: miramos la mirada del hermano vivo que prolonga el degüello de su hermano muerto. ( $\mathrm{Y}$ esa mirada es una mirada ciega: «y con negros tafetanes / la visiva luz les venda».) El horror sucumbe a la belleza y la

23 Sobre esa función, cito un fragmento de la Crónica Mexicayotl, de Fernando Alvarado Tezozómoc (en traducción de Georges Baudot): «Cet ancien récit, cet ancien écrit de Mexico, que l'on nous a légué, est à notre charge; et à notre tour, nous aussi, pour nos fils, pour nos petits-fils, pour notre sang et notre couleur, pour ceux qui seront issus de nous, pour qu'à leur tour ils le puissent garder, lorsque nous mourrons, nous leur laisserons»; Georges BAUdoT y Tzvetan Todorov, Récits aztèques de la Conquête (París: Seuil, 1983), p. 15.

24 El título completo del poema de Sandoval es el siguiente: «Relación fúnebre a la infeliz, trágica muerte de dos caballeros de lo más ilustre desta Nueva España, Alonso de Ávila y Álvaro Gil Gonzáles de Ávila, su hermano, degollados en la nobilísima Ciudad de México a 3 de agosto de 1566. Escribióla don Luis de Sandoval Zapata»; Luis de Sandoval Zapata, Obras (México: FCE, 1986), p. 69.

25 Sobre las ceremonias de ajustamiento como ritual y como espectáculo (con una "poética» implícita), consúltese el subcapítulo titulado «La resonancia de los suplicios» de Michel Foucault, Vigilar y castigar (México: Siglo XXI, 1980), pp. 38-74. 
cólera; la crítica se traduce en rabia contenida y, como escribe Buxó, las sangrientas imágenes de la desmembración de los cuerpos «darán lugar a imágenes de una sutil belleza perdurable: los miembros acuchillados, la sangre y su "rojo humor desatado", se transformarán en unas flores ideales (rosas y clavellinas ígneas)», o como repite más adelante, «rosas emblemáticas» ${ }^{26}$ :

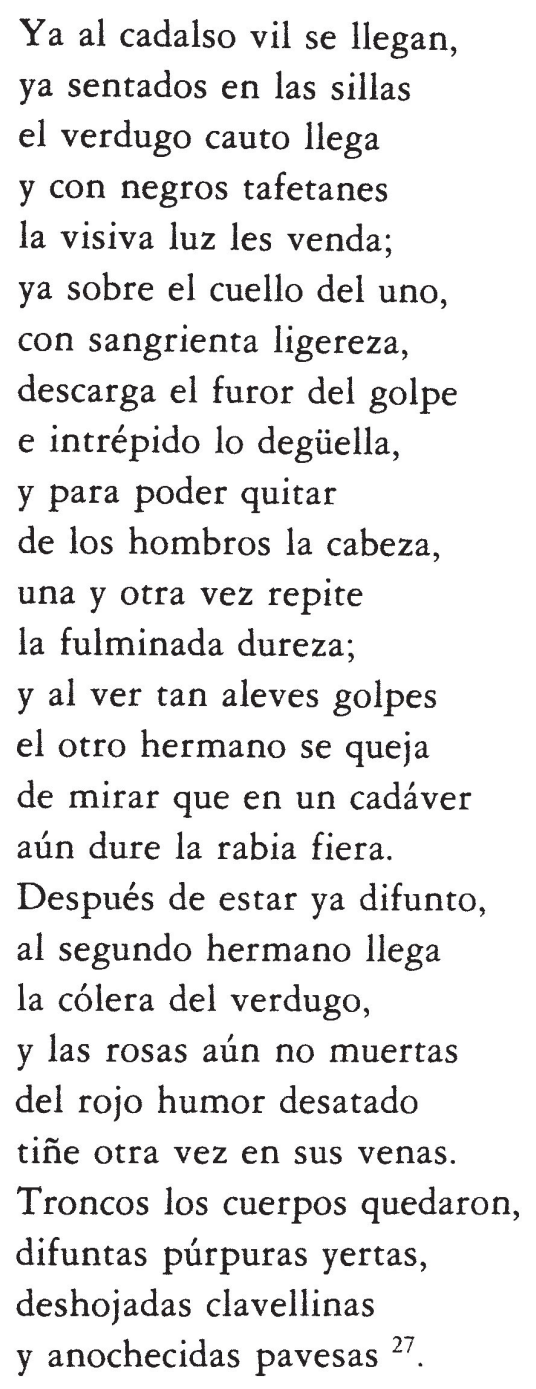

Todo parece alejar esta estrofa fúnebre de los romances de Patricio López: su fino acabado, su valor artístico nada despreciable, la crítica severa y sutil que teje su argumento, el criollismo que afina un estilo vulgar y que lo hermana al dolor de la nobleza criolla. Casi un siglo separa la relación de Sandoval de la degollación de los hermanos Ávila. Y ese siglo podría servir de emblema al abismo que media entre un «auténtico» ro-

26 José Pascual BuXó, «Luis de Sandoval Zapata: la poética del fuego y las cenizas», en Sandoval Zapata, op. cit., pp. 24-25.

27 Sandoval Zapata, op. cit., p. 74. 
mance vulgar (esa relación apócrifa o realmente contemporánea al suceso) y su recreación culta ${ }^{28}$.

El abismo que separa a Patricio López de Sandoval Zapata no se agota, por cierto, en la distinción entre un poeta «bueno» y un poeta «malo». El romancista vulgar trabaja en un universo discursivo extraño al del poeta culto:

Tendremos, por tanto, que hablar de retórica vulgar. (O también: semipopular [...].) De un estilo inconscientemente buscado y elaborado para agradar al vulgo callejero y al popular o popularizado. Un estilo que no es ni sublime, ni medio, ni humilde o bajo, sino una mezcla de todos ellos, informe y extraña [...].

$\mathrm{Y}$ así notaremos, tal vez, que son precisamente las subliteraturas [...] las que han hecho estallar la retórica antigua ${ }^{29}$.

La Relación fúnebre de Sandoval Zapata se inspira, como las relaciones de Patricio López, en las viejas «coplas de ajusticiados», que llegaron a ser, en el siglo XVIII español, un privilegio oficial reservado a los ciegos ${ }^{30}$. Sandoval, empero, no intenta «agradar» con ella al «vulgo callejero» (compuesto, en la Nueva España, por indios, mestizos y españoles y criollos empobrecidos), sino a lo mejor de la nobleza criolla. Su estilo no es una «mezcla» de géneros oratorios, aunque la imite y recree para hacer verosímil su asunto. En cierto modo, Sandoval restaura la unidad perdida de estilo y asunto, humildes si atendemos a la hora y el sitio, sublimes si atendemos a la vindicación del poeta.

4. En su afán de someter a estricto control estatal la difusión de «papeles impresos» (como las «coplas de ajusticiados»), el Consejo de Castilla publicó en 13 y 30 de enero de 1748 un decreto que destinaba las «rela-

28 Pero tampoco los romances de López son «auténticos» romances vulgares.

29 GARCIA DE ENTERRfa, op. cit., pp. 139-140.

30 Lo mismo vale para el siglo XIX, según el testimonio de Julio Caro Baroja, quien incluye entre las especialidades del ciego cantor de romances la «Causa y sentencia del reo que está en capilla con su nombre y apellido y cómo se llama». «Ocasión grave», comenta Caro Baroja, «para describir sufrimientos atroces»; y añade una copla extraída de un romance de ajusticiados:

Ya lo sacan de la cárcel, lo llevan por la carrera, hasta llegar a la plaza donde turbado se queda.

Julio Caro Baroja, Ensayo sobre la literatura de cordel (Madrid: Revista de Occidente, 1969), p. 60. 
ciones de los Reos ajusticiados en esta Corte para el socorro de los pobres ciegos» ${ }^{31}$.

Amparándose en ese privilegio, cada vez que la Hermandad escuchaba, «por noticia cierta, que está la tablilla puesta para ejecutar justicia con el reo que está en capilla de la Real Cárcel de esta villa», tenía derecho a obtener del «Relator de la causa del reo o de los reos [...] un extracto de la referida causa». Con ese extracto a su disposición, la Hermandad componía (o mandaba componer a otros) una relación en verso de los delitos del reo, las llamadas «coplas de ajusticiados», «para que los hermanos ciegos, como es uso y costumbre, la puedan vender al público para que sirva de universal escarmiento»:

L'on voit ici parfaitement le convergence d'interêts qui peut exister entre le pouvoir, les aveugles et même le public: la version oficielle des motifs de la condamnation à mort, inaccessible par sa diffusion restreinte et son langage à la majorité, doit cependant servir d'exemple, «de escarmiento» [...]. Elle est donc popularisée sous forme versifiée, par les aveugles, qui, malgré les arrangements «littéraires» qui ont pu être apportés «al extracto de la causa», donnent une version officielle des causes de la condamnation ${ }^{32}$.

Una vez compuesta la relación en verso, la Hermandad podía mandarla imprimir y venderla luego, si su impresión estaba ya lista, durante la ceremonia de la ejecución. Los propios ciegos se ocuparían, más tarde, de distribuir las coplas por las calles de la capital y en las otras ciudades y poblaciones del reino (pues como dice Botrel, «ce genre de littérature circulait beaucoup» ${ }^{33}$.

Ninguna imprenta novohispana del siglo XVIII publicó romances originales de este tipo, a excepción de los romances de López. Y si los publicó, no hay noticia de ellos. Como los ciegos de la cofradía madrileña, Patricio López versificó extractos de causas judiciales y puso en venta sus coplas como pliegos sueltos. La nota puesta al término de uno de sus romances impresos hace constar el privilego concedido al autor (cantor oficial de los «triunfos» de la Acordada), «para que él sólo, y no otra persona, lo

31 Sigo la exposición que hace de este decreto Jean-Francois BOTREL, «Les aveugles colporteurs d'imprimés en Espagne», Mélanges de la Casa de Velázquez, IX (1974), pp. $440-441$.

32 Ibid., p. 441. Botrel agrega, en nota a pie de página: «Une intéressante étude pourrait être menée grâce à une comparaison entre les extractos de las causas et les romances qu'ils inspirent».

33 Loc. cit. 
pueda imprimir por tiempo de quatro años» ${ }^{34}$. Y si los ciegos cofrades españoles formaron, como gremio, gracias al privilegio otorgado por la Corona, «une sorte d'élite parmi les classes misérables et eventuellement laborieuses» ${ }^{35}$, o una «clase aristocrática dentro de la pobreza» ${ }^{36}$, Patricio López fue él mismo (como su nombre de pila lo pone ya de relieve) un olvidado aristócrata de las masas indígenas novohispanas.

La publicación de los romances de López coincide, en el tiempo, con el nacimiento de la prensa periódica novohispana ${ }^{37}$. Juan Ignacio Castorena Ursúa dio a la luz, entre enero y julio de 1722, la primera Gaceta de México y Noticias de la Nueva España, cuya publicación no se reanudó sino hasta 1729, primero en la Imprenta de la Viuda de Rivera y luego en las prensas (importadas de España en 1722) de José Bernardo de Hogal ${ }^{38}$. A partir de enero de 1740 , año en que López compuso su Mercurio Indiano, la gaceta cambió su título por otro menos escueto y más afín a la durable sensibilidad barroca: Mercurio de México ${ }^{39}$.

Patricio López publicó sus pliegos entre 1723 y 1726. Uno de ellos fue impreso en la casa de la Viuda de Rivera, impresora, más tarde, de la gaceta oficial, y otros dos en la Imprenta de la Viuda de Ortega, radicada en Puebla, y que obtuvo, a partir de 1725 , el privilegio para publicar las esquelas y otros papeles oficiales en esa ciudad ${ }^{40}$. Hay, por tanto, que circunscribir esos pliegos a un proyecto de control estatal que incluyó, en esos años, una vertiente «popularizadora» de los procedimientos de la jus-

34 El privilegio aparece al término de su Breve, claro, llano, simple, narrativo, y verdadero romance, escrito en 1720 y autorizado en 1724 .

35 Botrel, art. cit., p. 428.

36 Así define José Gavira a la Hermandad de Ciegos, en frase citada por Botrel. Ibid., n. 4.

37 Sobre los orígenes de la prensa periódica en México, véase la síntesis de Heriberto García Rivas, Historia de la literatura mexicana (México: Textos Universitarios, 1971), t. I, pp. 484-487.

38 Sobre la Imprenta de Hogal, consúltese: José Toribio MEdinA, La imprenta en México (1539-1821) (Santiago de Chile: Impreso en casa del Autor, 1907-1912), t. I, pp. CLIX-CLXV.

39 Ya en 1693, don Carlos de Sigüenza y Góngora había publicado una relación histórica por entregas titulada Mercurio Volante. Se trata de una «noticia de la recuperación de las provincias del Nuevo México» que, en opinión de Sigüenza, «pedía para su relación no las hojas volantes que aqui están juntas, sino muchos pliegos de un gran volumen» (los subrayados son míos). Carlos de Sigüenza y Góngora, Obras históricas (México: Porrúa, 1960), p. 79.

40 Sobre la Imprenta de la Viuda de Ortega, consúltese: José Toribio MEDINA, La imprenta en la Puebla de los Ángeles (1640-1821) (Santiago de Chile: Imprenta Cervantes, 1908), pp. XXXII-Xxxv. 
ticia, capaz de satisfacer (y limitar, al mismo tiempo) la curiosidad política y literaria de amplias capas de la población novohispana'ajenas al resto de la cultura impresa.

Como los ciegos de la cofradía madrileña, Patricio López se vinculó, sin duda, con los ejecutores de la justicia. Tal es, al menos, lo que se desprende de la curiosa anécdota referida por López al capitán Velázquez Lorea (fundador y juez del Tribunal de Acordada) en uno de sus «triumphos contra vandoleros»:

Aviendo passado el Author, la primera vez a la Puebla, a imprimir la primera parte de estos Triumphos, y fatigádosele el Cavallo, le obligó a subir, y passar a pie el monte, que el camino atraviesa; y sabiéndolo el Provincial, le prometió dar un Cavallo ensillado, y escopeta, que por sus continuas ocupaciones, no se ha acordado [subrayo el juego de palabras], y oy se lo recuerda en estas Dézimas ${ }^{41}$.

Por sus vínculos con la cultura oficial, con la prensa oficial y con el aparato de impartición de la justicia, los pliegos de Patricio López (y en general las «coplas de ajusticiados») son la expresión apócrifa de una poesía popular que encuentra en lo apócrifo, precisamente, su expresión política privilegiada. Pues, como escribe Michel Foucault sobre este género de literatura:

En toda esta literatura de crímenes, que prolifera en torno de algunas altas siluetas, no hay que ver sin duda ni una «expresión popular» en estado puro, ni tampoco una acción concertada de propaganda y de moralización, venida de arriba, sino el punto de encuentro de dos acometidas de la práctica penal, una especie de frente de lucha en torno del crimen, de su castigo y de su memoria. Si estos relatos pueden ser impresos y puestos en circulación, es porque se espera de ellos un efecto de control ideológico, fábulas verídicas de la pequeña historia. Pero si son acogidos con tanta atención, si forman parte de las lecturas de base de las clases populares, es porque en ellos no sólo encuentran recuerdos sino puntos de apoyo; el interés de «curiosidad» es también un interés político ${ }^{42}$.

Tales discursos pueden ser leídos como «discursos de doble cara», por los sucesos que narran, por la repercusión que les dan y por las palabras mismas que emplean («desdicha», «abominación», «famoso», «lamentable» y otros vocablos igualmente ambivalentes). Desempeñan, a su manera, el papel de una «epopeya menor y cotidiana», previa a la bifurcación de lo criminal en sus vertientes literarias modernas: la «reescritura estética del

41 La anécdota en cuestión aparece en los segundos Triumphos de Patricio López, fechados en 1726. Los primeros Triumphos datan de 1723.

42 Michel Foucault, op. cit., p. 72. 
crimen» y la nota roja (con su «opaca monotonía sin epopeya de los delitos y de sus castigos»).

«Los bellos asesinatos», escribe Foucault, atento a la índole artesanal y popular de estos productos, «no son para los artesanos del ilegalismo» ${ }^{43}$.

5. El primer romance compuesto por Patricio López (aunque segundo en el orden de su publicación) corresponde, cabalmente, al viejo género artesanal de las «coplas de ajusticiados». Describo, a continuación, el pliego del poeta indio.

El título del pliego puede desglosarse, por la información que ofrece, en cuatro elementos fundamentales. El género de composición que presenta, expuesto en forma ripiosa e insistente: «Breve, claro, llano, simple, narrativo, y verdadero romance.» El argumento de la relación, declarado sumariamente:

A la violenta muerte que prodictoriamente executó Don Joseph de Estrada Tuñón, el día 13 de Julio del año de 1720, en el Coronel Don Gonzalo Gámez Mesía, Gentil Hombre de la Cámara de Su Magestad, y Governador, que fue de la Nueva Vera Cruz. [...] Con la punición del homicida, y degüello que en él se executó en la plaza pública de esta Corte.

Sigue la firma del autor, reiterada en cada uno de sus otros pliegos: «que entonzes escrivió Don Patricio Antonio Lopes, Cazique Zapoteco de uno de los Valles de Antequera.» Y, por último, la dedicatoria: «al Corregidor, y Juez, que fue de esta Causa, a cuyo zelo se devió el desagravio de la Justicia.»

Ni la firma ni la dedicatoria son elementos gratuitos en el contexto de los pliegos sueltos. Ambas forman parte de un aparato de acreditación del texto que autoriza la emisión del poeta y acredita la verdad de la relación (tan puntual como legítima pretende ser la condición de autor del cacique).

El pliego consta de ocho páginas sin foliar, a dos columnas separadas por orlas. En su primera plana, una lámina también orlada muestra la escena del degüello. La página final contiene una dedicatoria, en décimas, al juez de la causa, algunos de cuyos versos vale la pena transcribir en este apartado:

43 Sintetizo algunas de las conclusiones de Foucault, surgidas del análisis de lo que él designa como «discursos del patíbulo» o «últimas palabras de un condenado». Ibid., pP. 72-74. 


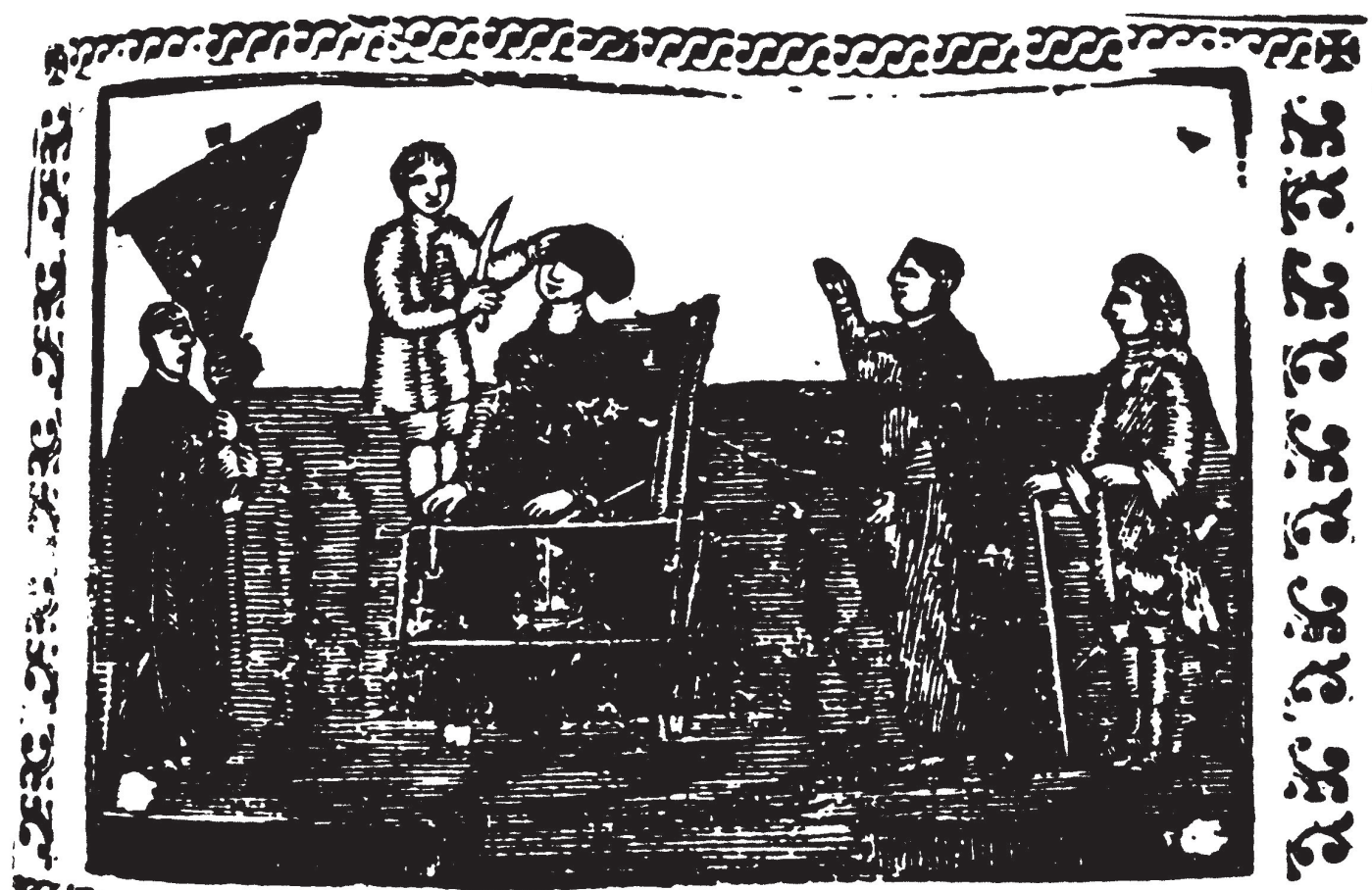

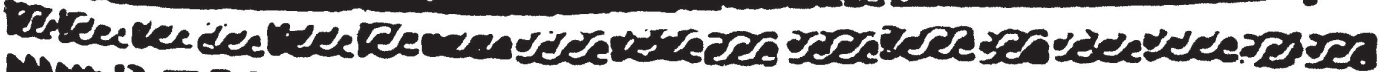
DREVE, CLARO, LLANO, SIMPLE, SNARRATIVO,Y VERDADEROROMANCE A LA VIOLENTA MVERTE,QVE

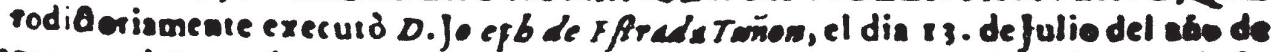

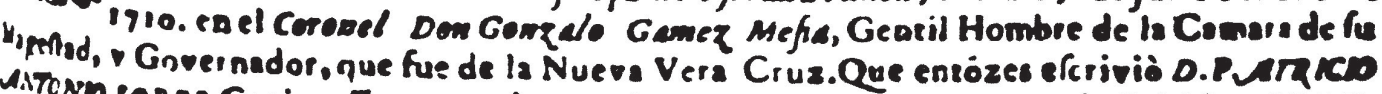
Astown cop rs, CesiqueZaporeco de vro de los Valles deAntequera,y dedicaAl ( ORKE.

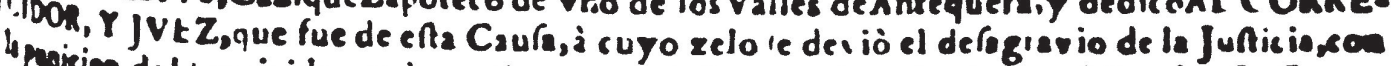

prajien del l.ovicida, y deguello que en el fe executò ea la plaza pubtica de ella Corte.

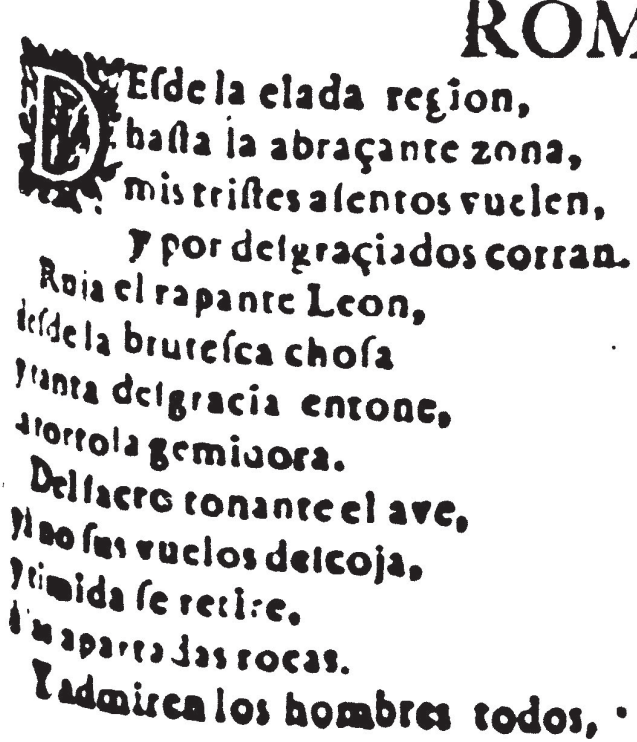
ROMANCE.

Spuesbiutos, y aresfe azoran, Cy del theatro de los Gglos. las vanas dicharconolcan. De D. GONZnLu areadieado, Flarragedia lanimola, Sal fon de milenta, iarda. atrille. deflempladariorba.

De Gentil hombre la plaza

Sobervo por fu perfona. E. que aun explendores de adentro, Eexteriorel caerpo informa.

La llave dorada Gempre. Pendieare rraxo por orla.

Fig. 1.-Encabezamiento del pliego con el romance de P. López: Breve, claro, llano, simple, narrativo y verdadero romance..., impreso en México en 1724. 
rifica fus columbres: Gloriofa ef denique frie yija listerd

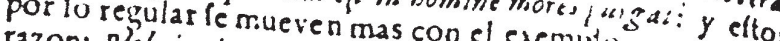
razon: rebeia ingenia exemrlos magis guo, que con la piuntur: Y con quien la razon no pueds, rolstome la miedo: Lat ratsone non pofunt eraduci a folo puede of metu contimentur: El es la feguridad you á meliora fa nos: Regna cupodis metus Con a cullodia de los kero pho de Tebas, horrorifies: Con cl, Phylonio Phylofo Horrificam fupelleitulem a el theatro de fus moratoro. demonios folvio $y$ er theatrum; quando de los de varas, lazos, $y$ en publico, en èl, fe prefentos Lace. res, rois, Crozos, cordeles, cataitas, prefento cargado res, roias, y Cruzes; dépues de vn alto flencio, equa pis diciendo. Veis aqui, o Ciudadanos de rea la caura del feliz eftado de lus anos de Thebas, qual es viciofo entre ellos in pen a ienen premonios, ninguno tud, y para todos los delinatienen premios para $/ 2$ Vit. caftigo, que propone a uetrics ellos intrumentos caura de que fus confum ares expectacion, y eft es a Pser Hieremi. tras. . que

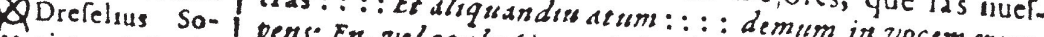

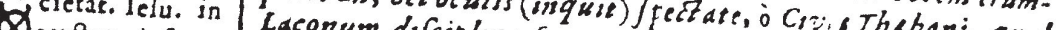

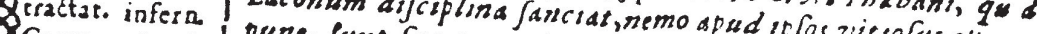

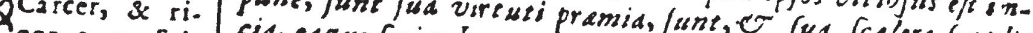

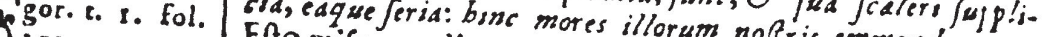

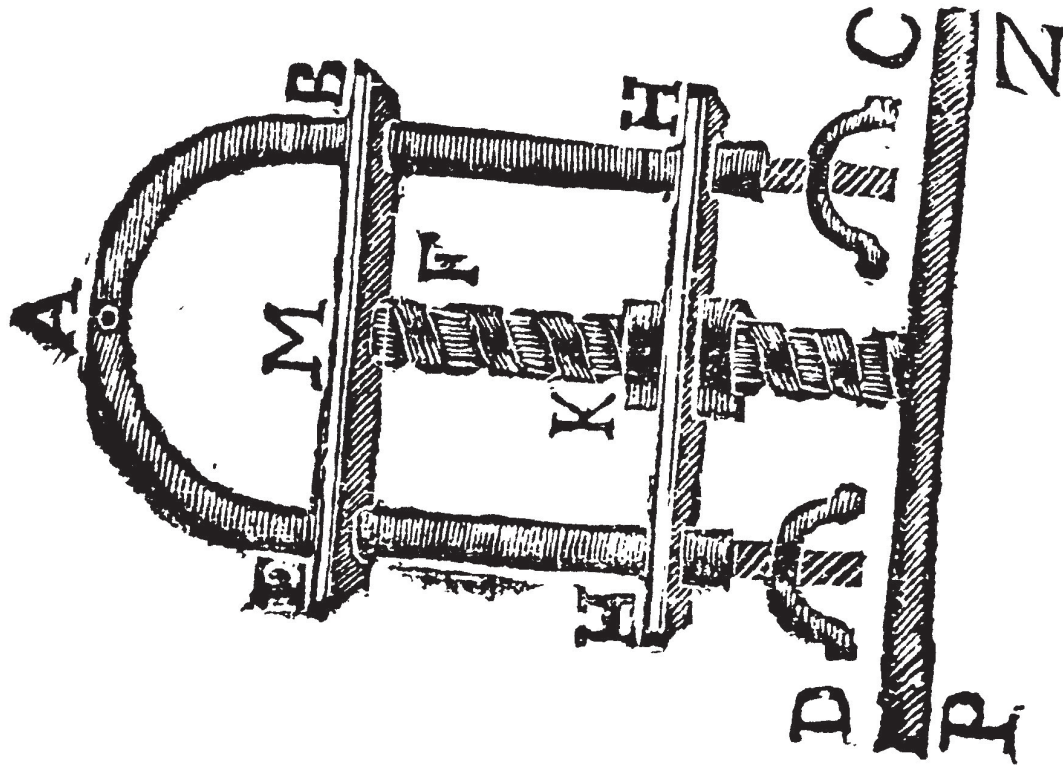

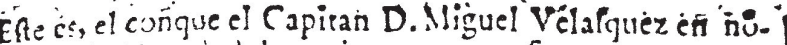
bre de lis Magentad, ha extirpado santos fieros grazatores; eftecs, el conque ha aterrado tancos intieles Ganzueros: Elte es, el conogite ha extinguido cantos naqurnos Ladrohe; y eite en in esjel cruiro equlcula horrible catafa, la bes, y elien grinora ka ala franuera del camino, con gurisad de la vida, la libertad dei Conercio, y el forsego tranguilo de los Citudadanos: Accepralo benigno, y con $\mathrm{el}$, el avifo que re inclu. ye en las claululas de elle pafel, lin que por pequeño re deba lo fevero del defrio, puesfuele a vezes debajo de vna corta, y mala capa, haver vna dilatada fabiduria: Sefe sss foduto falliolo laset fapientia: Nias, fi por mio te merece 1 afpereza de la fenfura, iendre folo el logro de caliticar de iel y yeneróo mi animo rolerando de til a injuria,

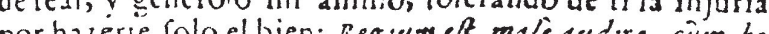
nefeceris: Prenio que folo laca, el que folo lo haze; y fiendolo alsi, afsi folo Vale.

\section{EXPLICACION DEL INSTRYMENTO.}

T A mayor parte del tormento, es el riempo que preceL de al cormento (dice el Cordoves Phyloropho) Quod antecedit tempus mixima fuplicijgars eft, y alsi es genero de mifericordia matar deprelto: Mifericordiegepuseft, soccoitere: Maxima, que movici al Provincial para la invencion ciel Intrumento figurado; cuyos movimientos re explican por las lerras del Alphabero A B C D, y E. Es cl principal Inftrumentc; culys dos puntas atraviefan el madero, y chapa de firro, que eniriangulo le guarnece, Saliendo atràs, hafta dar à ta C, y D, y fobre ellas cala luego el Verdugo el primer atravetano, que fe vè en la $\mathrm{F}$ y elte fe ajunta à el, y vnidos haren el medio circulo, que demueftsa la $A$ B, y E cojiendo la garganta del delinquenie entre la $M$, y A pegajo el cerebro a la Chare:a de dicho madero que eltara, verbigracia, en la $M$, y la nuez de la garganta en la $\mathrm{A}$. El regundo atravelaño, que demueltran las dos $\mathrm{HH}, \mathrm{y}$ que afianzan los tornillos de la $\mathrm{C}$, y $D$ es el que llama azia atris el referido Inftruntento entrando por la porquefuela de la K. El vifo corneado, cuyo abujon cae fobre el orro en dende fe vè la $f$, y en quié finca, y da fu torno, quedando afsi movibles dicho principal Inftsumento, fegundo atravefaño,y abujon,y torneado el Verdugu los dos eftremos del Perno, que le remata en donde eftan la Z, y P, ì dos bueltas y metia, llama azia atras de dicho madero, rodo el medio circulo, pesando la A a la $M$ cogiendola garganta en nedio, y afsi le vne la nuez con el cerebro, ahogando, tronchandole, y desha 2ien- 


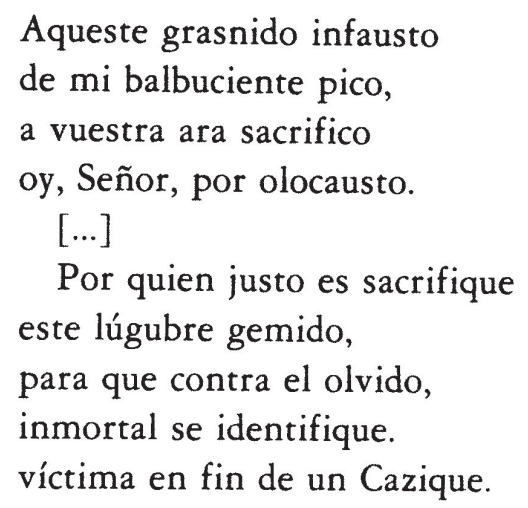

La analogía es luminosa: López equipara su canto con el chillido de un ave de rapiña, y lo ofrenda metafóricamente, en su calidad de indio y señor de indios, como una víctima propiciatoria en las aras de la justicia española.

El pliego incluye, asimismo, una décima dedicada «a los quatro Cavalleros, que acompañaron en la Iglesia a el agonizante», y otra décima dirigida al virrey y que implora el permiso para llevar el romance a la imprenta. Al término del pliego, una nota hace constar el privilegio concedido al autor para imprimirlo durante cuatro años. El colofón reza así: «Con Licencia de los Superiores en la Imprenta de la Viuda de Miguel de Ortega y Bonilla, año de 1724.»

Existe una Alegación ${ }^{44}$, impresa en 1720, que ayuda a paliar la ausencia de información periodística sobre el crimen que da pretexto a la relación de López. Aparte del alegato propiamente jurídico (presente también en la versión del cacique), el folleto extracta las circunstancias del crimen y restituye el romance al ámbito jurídico dentro del que fermenta: la casuística de la inmunidad eclesiástica; el universo de los doctores y los leguleyos, que pone su impronta formular y cultista en el vocabulario y las fórmulas del romancista.

La peculiar «delectación cultista» observada por Méndez Plancarte desborda, ciertamente, el ámbito de lo jurídico, como lo muestra el exordio del romance:

$$
\begin{aligned}
& \text { Desde la elada región, } \\
& \text { hasta la abraçante zona, } \\
& \text { mis tristes asentos vuelen, }
\end{aligned}
$$

44 Transcribo, fragmentariamente, el título de este documento: «Alegación, que se hizo en el Tribunal Metropolitano de México [...], sobre que se declarasse, que Joseph de Estrada Tuñón no debe gozar la inmunidad de la Yglesia por el homicidio que executó en el Coronel Don Gonzalo Gámez Messía Gentil-Hombre de la Cámara de su Magestad, y Governador que fue de la Ciudad de la Nueva Veracruz. [...] Que por sentencia pronunciada el día 27 de Julio de este Año, se declaró no deber gozar dicho Reo la inmunidad [...]. Con Licencia: En México, en la Imprenta del Superior Govierno, por Francisco de Rivera Calderón, en la Calle de San Agustín. Año de 1720.» 


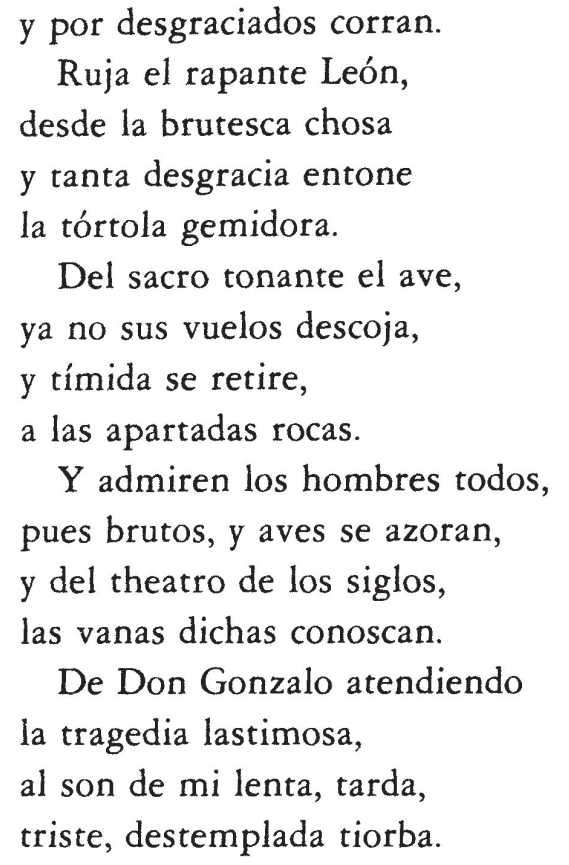

Estos versos de Patricio López cumplen con una ley de la elocuencia vulgar que quiere que sea en los exordios de sus romances donde los autores de pliegos sueltos acumulen «todo lo que de retórica saben o se imaginan saber, con recurso a imágenes mitológicas, comparaciones atrevidas y palabras cultas» ${ }^{45}$.

Pero este tipo de exordios «no eran más que variantes o combinaciones de una materia conocida bien por las gentes de su oficio y por su público»: el recurso al ripio, la petición de atención, el énfasis en lo grave del caso (la «tragedia lastimosa»), el instrumento humilde de que se sirve el poeta («mi lenta, tarda, / triste, destemplada tiorba» ${ }^{46}$ ), la expectativa desmesurada que el romancista espera despertar en su público, todas estas son «técnicas que van a durar y perdurar en la poesía de cordel», emparentadas con otros géneros orales y semiorales, juglarescos y notariales, cultos y populares ${ }^{47}$.

45 Garcfa de EnTERrfa, op. cit., p. 163.

40 La «tiorba» de Patricio López reaparece en los primeros Triumphos: «De este al contrapuesto Polo, / resuenen Tiorbas acordes...». Sobre el origen de la palabra «tiorba», dice Corominas que proviene del italiano tiorba (palabra que designa un «instrumento inventado en Italia»). Y añade: "Origen incierto; será aplicación traslaticia del italiano dialectal tiorbo "miope, cegato", por ser propio de músicos callejeros medio ciegos»; Joan COROMINAS, Breve diccionario etimológico de la lengua castellana (Madrid: Gredos, 1983), p. 569.

47 María Cruz GARCfa de ENTERRfa, Literaturas marginadas (Madrid: Playor, 1983), p. 73. La autora pone el énfasis en la influencia de «ese otro género semioral que es el sermón», pero no, por ejemplo, en las prácticas oratorias de los tribunales. 
Pero, en el caso de Patricio López, el deleite cultista no se circunscribe al exordio del discurso. El «gusto por los conceptos alambicados, las metáforas y los vocablos un poco misteriosos de contenido» ${ }^{48}$, ese gusto permea la totalidad del romance. Atiéndase, por ejemplo, a la evocación del cadalso:

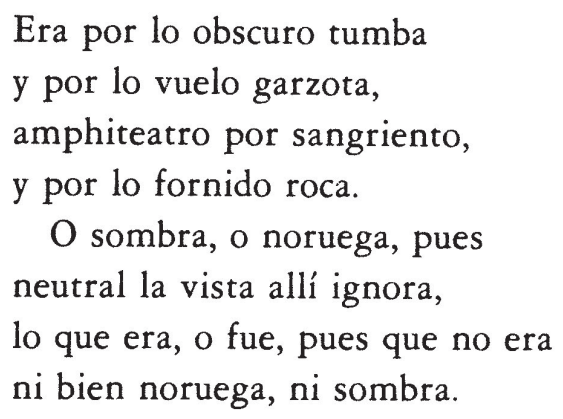

Cualquier lector familiarizado en las Soledades de Góngora identificará en estos versos la reminiscencia de los halcones gongorinos, esos «raudos torbellinos de Noruega» ${ }^{49}$ que, cegados y aprisionados en el guante de los halconeros, son una imagen de la fría desolación y (en el contexto del romance de López, que asocia el patíbulo con una garzota en vuelo) de la rapiña.

En cuanto a la presencia del vocabulario forense, basta con señalar, en la escena misma del suplicio, la «mano interfectora» del verdugo, la «facción más prodictora» del criminal y el «bufete» instalado sobre el cadalso, por no hablar del extenso alegato jurídico (pretexto para otras tantas alusiones bíblicas y clásicas) que, «en literal palestra», argumentan abogados y doctores desmenuzando textos y esgrimiendo sentencias y glosas de los «Theojuristas».

48 Julio Caro Baroja, op. cit., p. 183. «QQúe extraño encanto debían tener para oídos andaluces los conceptos calderonianos!», dice Caro Baroja, comentando la preferencia del público de la época de Felipe $\mathrm{V}$ por las obras de Calderón, y el gusto barroco y altisonante de los lectores de pliegos de cordel. ¡Con cuánta más razón no habrá arraigado ese encanto en los oídos de indios y de mestizos, tan embebidos de barroquismo popular!

49 Las palabras «noruega» y «garzota» forman parte de un mismo juego metafórico, de un mismo juego de luz y sombras que vuelve a encontrarse en la acepción de "garzota» como "plumaage o penacho», adorno de arte plumario, jaez equino que traslada Quevedo a una de sus «Xácaras» (a la que alude el poeta indio):

La cabeza del verdugo

le servía de garzota.

Diccionario de Autoridades (Madrid: Gredos, 1984). La «autoridad» de Quevedo va acompañada de la referencia siguiente: Quevedo, Musa 5, Jácara 11. 
Lo extraño, en todo caso, es que esta gala de erudición «literal» y retórica conviva con la llaneza y la simplicidad que engalana también al romancista:

\author{
$\mathrm{Y}$ aquí mi encogida pluma \\ pause el remonte por bronca, \\ dando de estos Caballeros, \\ fin, la desdichada historia.
}

6. Para comprender la figura del capitán Velázquez Lorea, héroe de otros dos pliegos de Patricio López, hay que hacer un poco de historia ${ }^{50}$. A partir del alboroto de 1692, graves conflictos sociales encontraron salida en el crimen. La despoblación causada por las epidemias de los siglos XVI y XVII produjo una escasez de mano de obra indígena que puso en crisis la economía novohispana. Hubo que recurrir, entonces, a la mano de obra de los convictos, condenados por los jueces locales a una gran variedad de sentencias de obraje. Incluso los indios nobles, exentos hasta entonces del trabajo forzado, tuvieron que ingresar al mercado de la mano de obra. Para colmo de males, los propietarios de tierras aprovecharon los cambios demográficos para apropiarse las tierras de los indios, afectando seriamente la producción y enfrentándolos a una terrible escasez de alimentos. El bandidaje invadió la totalidad del virreinato y ni el Palacio Virreinal quedó fuera del alcance de los ladrones.

En este contexto se creó, por acuerdo del virrey y la Audiencia en 1722, el Tribunal de la Acordada, cuyo primer capitán y juez propietario fue don Miguel Velázquez Lorea. Velázquez organizó el Tribunal en torno a un pequeño grupo de administradores pagados, compuesto por un secretario y un ayudante, un asistente médico, un capellán y un carcelero. La energía y la crueldad desplegadas por Miguel Velázquez se hicieron muy pronto legendarias. La justicia sumarísima practicada por el Tribunal sirvió de argumento contra infractores y espectadores, como se desprende de las octavas compuestas por el filipense fray José Rincón y grabadas en piedra en el frontispicio de la Cárcel de la Acordada:

\footnotetext{
Pasajero: respeta este edificio,

Y procura evitar su triste entrada:

Pues cerrada una vez su dura puerta,
}

so Me apoyo, para la redacción de este párrafo, en la investigación del historiador Colin M. MAC LACHLAN, La justicia criminal el siglo XVIII en México; un estudio sobre el Tribunal de la Acordada (México: Sep-setentas, 1976). 
Sólo para el suplicio se halla abierta ${ }^{51}$.

No extraña, pues, que los archivos correspondientes a la judicatura del capitán Velázquez sean hoy inexistentes (ya el juez Martínez de la Concha, sucesor de Velázquez, dijo haberlos encontrado metidos en cajas y en un estado de negligencia y desorden totales). Resta sólo una lista, hecha cincuenta años más tarde, con los nombres de los reos ajusticiados y el catálogo de los cuerpos del delito. Hechas en los caminos a vuelapluma, esas causas sumarísimas eran instruidas por un escribano en el lugar mismo de la aprehensión, llenando apenas un folio de papel manila, y a veces ni siquiera eso.

Los pliegos de Patricio López son uno de los mejores registros de las hazañas del capitán Lorea, o al menos de su popularidad legendaria. Las intermitentes gacetas de la época dan noticias sobre el temido y casi todopoderoso juez: algún nombramiento, aquí y allá algunas ejecuciones, la hora de su muerte. Vale la pena transcribir unas líneas de la Gazeta de México del mes de septiembre de 1732: «el 7 murió a los 62 años de su edad el capitán don Miguel Velázquez Lorea, natural de Querétaro, alcalde provincial de la Santa Hermandad de este reino, alguacil mayor de la Inquisición, etc.» Y agrega: «en el tiempo que tuvo la Acordada, que fue desde el año de 1719, hizo justicia en cuarenta y tres que ahorcó, en ciento cincuenta y uno que azaeteó, y en setecientos treinta y tres que envió a varios presidios de este reino» ${ }^{52}$.

Como profetizó el padre Margil en Querétaro, quince años atrás, la muerte del capitán Velázquez Lorea fue «como la de una religiosa Capuchina» ${ }^{53}$.

31 El texto de las tres octavas puede encontrarse en la crónica de Artemio de VAlle-ArizPe, «La Acordada, sepultura de vivos», en VAlle-ArizPe et al., Historia de la ciudad de México (México: Robredo, 1939), pp. 463-478.

52 «Gazeta de México, desde primero hasta fines de septiembre de 1732. Con Licencia, y Privilegio del Excelentíssimo Señor Virrey. En México, en la Imprenta Real del Superior Govierno de Doña María de Rivera, en el Empedradillo.»

53 La profecía del padre Margil se registra en el «Sermón Epidíctico que en las Honras, que [...] hizo el día 22 de Septiembre de este año de 1732 el Convento Grande de Nuestro Padre San Francisco de esta Ciudad de México al Cappitán Don Miguel Velázquez Lorea [...]. Predicó el Reverendo Padre Fray Diego Antonio de Escobar [...]. Con Licencia de los Superiores. En México: Por Joseph Bernardo de Hogal, Ministro, e Impressor del Real, y Apostólico Tribunal de la Santa Cruzada en todo este Reyno [p. 15]». 
7. Además de una aparatosa dedicatoria al virrey (cargada de apellidos y títulos honoríficos), el título de los primeros Triumphos del poeta indio contiene dos elementos centrales. En primer lugar, el argumento de la relación, idéntico al género de poesía que se practica: «Triumphos aclamados contra Vandoleros por la Real Justicia que [...] a conseguido el Capitán Don Miguel Velázquez Lorea, Provincial de la Santa Hermandad, en este Reyno». Y luego, la firma habitual del romancista, trazada por «la encogida pluma de Don Patricio Antonio López, Cazique originario del Obispado de Antequera, Valle de Oaxaca».

Ambos elementos parecen alejar a Patricio López de los «autores o poetas de cordel auténticos» (si es que la noción de «autenticidad» puede aplicarse a un género de literatura tan radicalmente apócrifo ${ }^{54}$ como el romancero vulgar) $s$.

Los únicos datos que sobre sí mismos nos dan los autores populares o vulgares son los del lugar de su nacimiento y el de su residencia o vecindad [...]. A partir de $1620[\ldots]$, los poetas de cordel, tal vez por influjo de los autores cultos que no perdonan título ni oficio de que hacer gala al reseñar su nombre, empiezan a añadir otros datos «honoríficos», de los cuales es el más abundante el de $L i$ cenciado, seguido por Doctor. Solamente en cuatro pliegos populares o semipopulares aparece el nombre del autor precedido del Don ${ }^{56}$.

En cuanto a las dedicatorias, «apenas existen entre los pliegos de cordel auténticos»y, cuando existen, están dirigidas a personajes «con menos importancia, cargos y títulos que los destinatarios de los pliegos cultos» ${ }^{57}$.

Más que como un autor popular o «semipopular», podríamos caracterizar, entonces, a Patricio López como un autor «seudoculto», como un artífice inmerso en el universo de la poesía de cordel, pero que no deja de ubicarse, por ello, en los márgenes de la poesía culta. Y entre esas dos categorías de análisis (lo «seudoculto» y lo «semipopular») oscila el trabajo del poeta vulgar.

${ }^{54}$ La palabra del ciego es (en términos de la recepción de sus versos en los Siglos de Oro) una palabra inauténtica. El ciego plagia y atenta contra el derecho de autor; propaga historias falsas como verdaderas; su figura dibuja una figura alterna, la del «ciego fingido" ( $\tan$ popular en la historia de la literatura). El ciego es un autor apócrifo y su palabra una palabra apócrifa, fabulosa, apoyada en la autoridad del texto escrito e impreso.

55 Más que autores «auténticos» e «inauténticos» de poesía de cordel, hay en los pliegos sueltos una construcción de la autoría del romance y una transgresión de la ley de autor que tienta también a los poetas cultos.

56 María Cruz Garcia de EnTERrfa, Sociedad y poesía de cordel en el Barroco (Madrid: Taurus, 1973), p. 119.

5 Ibid.. pp. 119-120. 
El pie de imprenta aparece al fin de la portada del pliego: «Con Licencia de los Superiores en la Puebla de los Ángeles en la Imprenta de la Viuda de Miguel de Ortega, en el Portal de las Flores. Año de 1723.» Se trata, pues, del primer romance impreso de Patricio López (aunque las coplas ya reseñadas hayan sido escritas en 1720). Con él afrontó el cacique la prueba de la censura y en él se registran los datos que otorgan al indio la calidad de «autor».

El pliego consta, en efecto, de veinte páginas sin foliar, de las cuales únicamente ocho (impresas a dos columnas) corresponden al texto del romance. Los seis folios restantes componen el aparato de acreditación del texto.

A la cabeza de este aparato están las licencias del virrey y del ordinario, seguidas de tres hojas preliminares con la «Dedicatoria» al virrey y la «Real Cédula de gracias» al capitán Lorea. Por las metáforas, citas y alusiones bíblicas que despliega, el texto de la «Dedicatoria» emparenta con la oratoria sagrada y justifica teológicamente la furia contra los bandoleros.

Varias censuras y aprobaciones ocupan otros dos folios del pliego. Una de ellas alude a la condición racial de Patricio López, «y a que el impedimento que se dezía tener por Indio, y que como tal no devía escrevir, no lo es en la realidad» el subrayado es mío). Otra censura amplía la defensa de López, ponderando la «claridad corriente» de su poema y «la bien nacida hidalguía de su locución» derivada, a su vez, de la condición patricia del poeta indio).

El mismo censor, «Professo de la Sagrada Compañía de Jesús», llama al lector a poner «con discreción los ojos» (al lector discreto, se sobrentiende), no en la aspereza de cláusulas, frases, conceptos y estilo, sino «en el author de la obra».

El énfasis puesto en la condición racial y social del cacique se extiende o traslada, entonces, a su condición de hablante adoptivo de la lengua, pero también a la naturaleza casi artesanal (o erudito-artesanal) de su trabajo:

Porque hablando el author, como Cazique, en una lengua, si no peregrina por lo menos sin aquel embarazo de nativa, no es poca gracia aver reducido a metro constante, y ajustada consonancia su argumento, taraceando [subrayo este símil] la narración de sentencias, y aluciones que trae, y apunta, la aplicación y curiosidad de Don Patricio.

En cuanto a la nota de vulgar que pesa sobre el estilo de López (el «varajarse con el vulgo» que su mismo defensor desaprueba), el censor recomienda tomar en cuenta el «limitado alcance» del público al que se destina el romance. $\mathrm{Y}$ agrega luego: «los sujetos que aliciona con este su 
trabajo son aquellos que por la escasa condición de su suerte, o por la corta esphera de sus empleos, viven arresgados a incurrir en semejante desdicha» (la del bandolerismo).

Una vez construidas las figuras legales del autor y del público, el pliego cede la palabra al poeta. En un párrafo impreso al término del romance (la oratoria «Protesta del Author a quien leyere»), Patricio López replica y niega haber escrito el romance «con presunción de adquirir el honorífico título de Coronista, Escriptor, ni Poeta». «Ni tampoco lo he hecho», añade unas líneas más adelante, «para quitar la nota que padecemos los Indios de inábiles».

Simple «pregonero» de extrañas proezas, el romancista canta para impedir que perezcan «las gloriosas acciones de los invencibles capitanes». Y así como celebró Homero las hazañas de Aquiles, López consigna en su relación (circunstanciadamente, con alusiones clásicas y mitológicas incesantes) la furia y excesos de los bandoleros, la fomación de las huestes de la Acordada, la resistencia de las principales gavillas y (en un estilo ágil, que mueve y suspende los ánimos) los triunfos de las «bolantes esquadras» de Miguel Velázquez, la conducción de los reos a Chapultepec («que Alcázar / fue de Indios Emperadores») y la hecatombe de los cuarenta bandidos ajusticiados en el bosque.

La trágica historia del indio don Juan Zerón, jefe de una cuadrilla de bandoleros, forma un episodio aparte dentro del romance. Vale la pena reconstruir los fragmentos de esa «epopeya menor» que, como un espejo disonante y disforme, reproduce, dentro del romance, la figura contrahecha del romancista.

Cuenta López que, irritado Zerón por los primeros triunfos del capitán Lorea, protestó, «en un villete», vengarse de él dándole «muerte enorme»:

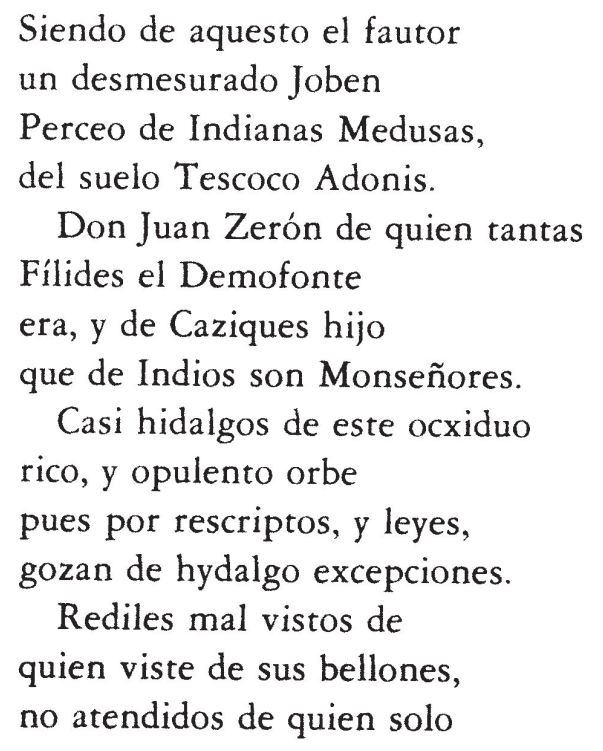


en lo albo busca lo noble.

De aquesto a degenerar vino, y de su illustre prole, estaño dando por plata, por estos quilates, cobre.

Sin ver que los hombres son ríos caudalosos, que el nombre toman del sitio en que pasan, y no de onde se componen.

Más allá del prosaico descuido de la versificación de López, el pasaje presenta dos rasgos dignos de señalarse. Primero, la inopinada apología de los indios (o de los privilegios de los indios nobles) que aflora en el ámbito justiciero del romance. Y segundo, la «doble cara» del discurso de López, que si bien condena las desmesuras del indio, reviste también su figura con los prestigios de la mitología y con el aura popular de los bandidos nobles.

La captura de don Juan Zerón tiene algo de melancólico y lamentable:

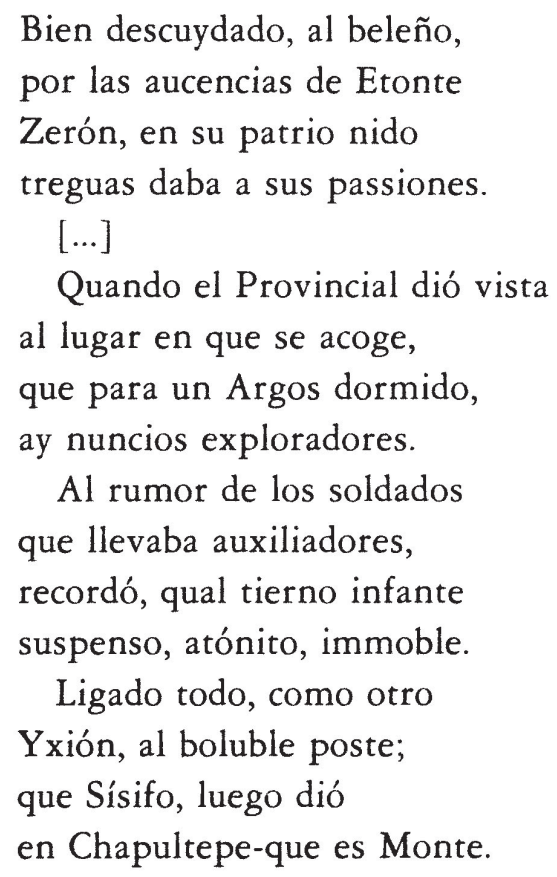

Preso el indio don Juan Zerón en el que fuera Alcázar de sus antepasados, López se extiende en la relación de la captura de sus consortes. Finalmente, el 21 de febrero de 1722, los ecos destemplados de la trompeta anuncian el comienzo de las ejecuciones. Las mulas de los condenados surcan el río de gentes que vienen a contemplar el suplicio, como si se tratara de otros náufragos en las «chalupas de Aqueronte». El ruido de trompas 
y pregones se entremezcla con las doctísimas voces de los religiosos que exhortan a los bandidos.

El agarrotamiento de don Juan Zerón ocupa un lugar principal, si no en los fastos de la Acordada, sí en las coplas del romancista y cacique Patricio López. Un acento elegíaco sobrenada la voluntad de escarmiento del romance:

\author{
Continuóse esta de Dios \\ obra, y en las succesiones \\ de Marzo, Zerón se vió \\ por singular en el vozque. \\ Contiguo al Alcázar Regio \\ que ya hase entre soportones \\ triste, lóbrego, y frondoso \\ de pinos, ayas, y robles. \\ Muerto al pie de un mal labrado \\ basto, y desmedido poste \\ suplicio de sus delictos, \\ término de sus errores.
}

En este punto, el romancista entona un lamento por la muerte del bandolero indio, que se atrevió a desafiar la autoridad del capitán Velázquez y cuya hermosura y gallardía realza la intrepidez de sus crímenes y de sus desórdenes:

\author{
Solos veinte, y tres Abriles \\ contaba el Indiano Joben \\ Narciso, por lo gallardo, \\ por lo bien dispuesto, Adonis. \\ Mas a esta edad excedieron \\ tanto sus hechos enormes, \\ que fue tanta pena poca, \\ a esta poca edad, sin orden. \\ Diez, y seis famosos robos \\ todos a varios viadores, \\ plenos le justificaron, \\ por justas disposiciones. \\ Entre todos, fue uno dando \\ el asalto a unos Dragones \\ que a la Vera-Cruz vajaban \\ un pagamento de importe. \\ Derotándolos alebe, \\ quitándoles los doblones \\ intrépido, qual si diera \\ sobre enemigos comboyes.
}


Mas con Sylvestre a morir vino, que era su consorte, que hasta lo sylvestre muere a manos de su desorden.

En los primeros Triumphos de Patricio López, el indio canta la proscripción del indio, pero también glorifica sus hechos delictuosos. Amparada en el brillo de la tradición y la nobleza indígenas, la «figura reversible» del criminal (para emplear otro término de Michel Foucault ${ }^{58}$ ) asocia la gloria y la abominación en la lectura equívoca y secreta de los romances de bandoleros.

En este nuevo avatar del romance mestizo, aún es un príncipe quien entona las elegías de los príncipes mexicanos. Pero ese príncipe se ha convertido en mendigo: miserable juglar que, como los ciegos de España, pregona los «triumphos» de la justicia a cambio de una escopeta y «un Cavallo ensillado». Y el príncipe se ha convertido, también, en bandido: híbrido ejemplar indígena de los tan populares «bandidos nobles» de las baladas y romances vulgares 59 .

Pues los «vandoleros» de Patricio López (y don Juan Zerón, en particular) no son vulgares ladrones, sino virtuales rebeldes alzados contra la Corona:

\author{
Quarenta han pagado assí \\ sus latrocinios, y errores, \\ que ya contra Dios, y el Rey, \\ enarvolaban pendones.
}

8. El título del último pliego impreso por Patricio López incluye cuatro noticias fundamentales. Las dos primeras corresponden al argumento del romance, que añade a la de los «triumphos» del capitán Lorea una segunda relación, un segundo argumento interpolado y anunciado en el título (con un ladrón, con un antihéroe como protagonista, como en los más populares romances de ciego):

Triumphos que la Real Justicia ha conseguido de otros 40 Vandoleros [subrayo la transición] con los hechos en la vida; y estremos en la muerte, de Manuel

58 Michel FoucaulT, op. cit., p. 72.

59 Para una semblanza del «bandido noble» en la poesía popular europea, consúltese el capítulo «El ladrón noble» de Eric J. HoBSBawM, Bandidos (Barcelona: Ariel, 1976), pp. 44-65. 
Calderas, uno de sus principales Caudillos, condenado con todos sus Compañeros por famosos Grazatores, en la pena de el último suplicio: Por el Capitán Don Miguel Velásquez Lorea, Alguacil Mayor de el Tribunal de la Santa Inquisición, Alcalde Provincial Juez de la Cordada, de este Reyno, y de el de la Nueva Galicia.

Una tercera noticia apoya, escrituraria y harto gráficamente, el mysterium tremendum ${ }^{60}$ de la poesía de cordel: «Lleva estampado el horroroso, y férreo instrumento conque se haze justicia en los Delinquentes.» Y el título agrega una última noticia, imprescindible para caracterizar la figura del autor del pliego, que lo firma así: «don Patricio Antonio López, Cazique de la Nación Zapoteca, en los Valles de Antequera: y uno de los que pretendieron ocupar, interinaria, la plaza de Solicitador, y Agente de negocios de Naturales.»

Aquí se perfila ya el futuro burocrático del romancista, su ascendente carrera de intérprete. El pie de imprenta aparece al fin de la portada (orlada, igual que la de los primeros Triumphos): «Con Licencia: En México por los Herederos de la Viuda de Miguel de Rivera, en el Empedradillo. Año de 1726.»

El pliego consta de doce páginas sin foliar, pero sólo las cuatro últimas (impresas a dos columnas y separadas con orlas) corresponden al texto del romance. Las licencias del virrey y del ordinario ocupan la vuelta de la portada, junto con unas décimas dedicadas al capitán Velázquez Lorea y destinadas a exigir los «despojos» («un Cavallo ensillado, y escopeta») de los «triumphos» del Provincial, en consonancia con la anécdota antes citada.

Las cinco páginas siguientes contienen un «Preludio» dividido en varias secciones. Una de ellas -otra «protesta del Autor a quien leyere»- retoma en su título y en su contenido el párrafo final de la primera parte de los Triumphos y justifica, como ella, la desnudez de «ambages rethóricos» del romance:

Mayormente [escribe López], quando se dirige, no sólo a tu discreción política, que se me disculpará benigno lo escabroso del estylo, y lo inculto del rythmo; sino también a los que por sus rústicos empleos, viven apartados de las letras, y agenos de la sciencia.

60 «El tremendismo ha constituido siempre parte del instinto literario popular. Pero los ciegos cantores de romances [...] no podían pensar en la existencia de un tremendismo laico o laicificado [...]. Lo tremendo para ellos estaba siempre ligado, de una manera u otra, a lo religioso. Era, usando una fórmula conocida para los historiadores de las religiones, mysterium tremendum»; Julio CARO BAROJA, Romances de ciego (Madrid: Taurus, 1980), p. 10. 
Ahora bien, como estos iletrados «por lo regular se mueven más con el exemplo, que con la razón», «y con quien la razón no puede, sólo puede el miedo», el texto propone a nuestra «expectación» (a modo de imagen más cierta del castigo) el instrumento de las ejecuciones del capitán Miguel Velázquez Lorea:

Esto mismo te digo, te presento, y demuestro en el instrumento que aquí figurado ves [y reproduce, en efecto, el artefacto en un basto y primitivo grabado en madera]. Éste es, el conqué el Capitán Don Miguel Velásquez en nombre de su Magestad, ha extirpado tantos fieros grazatores; éste es, el conqué ha aterrado tantos infieles Ganzueros. Éste es, el conqué ha extinguido tantos nocturnos ladrones.

El «conqué» en cuestión es una suerte de garrote portátil, inventado (según dice don Patricio) por el propio capitán Lorea. Está ideado para «matar depresto», sirviendo a un fin de misericordia. Pues, como dice el «Cordovés Phylosopho», «la mayor parte del momento, es el tiempo que precede al tormento».

La sección titulada «Explicación del instrumento» expone muy en detalle -analítica, fría, alfabéticamente- los diferentes giros y presiones del aparato, en una escalofriante descripción digna sólo del artesano del terror que inventa el instrumento. El rechinante accionar de sus piezas -maderos y «atravesaños», chapas de hierro, tornillos, «abujones», pernos y "porquesuelas»- corresponde al accionar del verdugo con la cabeza absorta del delincuente:

Y assí [concluye la «explicación»] le une la nuez con el cerebro, ahogando, tronchándole y deshaziéndole en un momento, y a un mismo tiempo crujen, garganta, nuez, y cerebro; y assí espira con la mayor brevedad, que imaginarse puede; sin reportar la dilación del tormentoso cáñamo, que reportaron los primeros quarenta que espresé en la primera parte de estos Triumphos, impressa el año de 1723.

«Escarmentar», aterrorizar a un público en su mayoría iletrado es objetivo central de esta literatura. Ese objetivo se cumple de diversas maneras: por medio del grabado y la imagen visual; a través del canto o la recitación del romance; por la vía de la letra, como en un ritual de ajusticiamiento «técnico».

El terror es, pues, una de las dos categorías poéticas que rigen la lectura de este pliego de Patricio López. La otra es la piedad, un elemento que cobra su mayor relieve en el desenlace de este último pliego del cacique.

Antes de adentrarnos en ese desenlace, vale la pena insistir en el trayecto que cubre el criminal entre los primeros y los segundos Triumphos. El bandolero se ha convertido en héroe en virtud de una singular trayec- 
toria, protagonista central de los sucesos narrados que parece opacar, con sus sangrientos crímines, al temible juez del Tribunal de Acordada. Así lo asevera la historia sumaria de los «hechos» de Asensio López, puesta en una nota por Patricio López y que forma, a su modo, el argumento de otro romance de bandoleros:

Hechos de Asensio López, terror que fue de las Cordilleras de la Nueva Galicia, Zacatecas, Querétaro, y Durango; por sus continuas hostilidades: y la de otros 50 Vandoleros de quienes era Cabo, y Caudillo; saqueando de los poblados, casas, robando Sacrílego los Templos, y en los Campos, las Haziendas, y Rancherías, y en ellas obsenamente extrupando las Doncellas, y forzando las Casadas, a quienes después, con sus Hijos, Padres, y Maridos, daban muerte.

Por su novelesca y llana relación de las infamias del bandolero, los «hechos en la vida» de Manuel Calderas siguen, paso a paso, la línea trazada en el argumento recién transcrito. Pero otra cosa sucede con su desenlace, al que aludía la cláusula interpolada en el título de modo aparentemente formulario: «con los hechos en la vida; $y$ estremos en la muerte, de Manuel Calderas».

Apresado y convicto Calderas por la comisión de cincuenta robos y tres homicidios, el juez notifica su condena al reo «en la pena de el último suplicio»:

De veinte y quatro iba el año ya sobre el Abril corriendo, quien vio veinte y siete vezes en su Zenit a Timbreo.

Quando al infeliz Calderas, y su Consorte Viveros, el recto Juez le pronuncia el házido fin tremendo.

Que pérfido, e inobediente a el venerado precepto, oprobios contra el Juez lansa, y contra la Ley denuestos.

Enojoso, y furibundo, irreverente, y blasfemo, desprecia al Sacro Hazedor, y Juez de vivos, y muertos.

Sólo sí, implora le auxilie, en aquel tránsito acervo, la venenosa potencia del espantoso Letheo.

Los Presbyteros, que son 


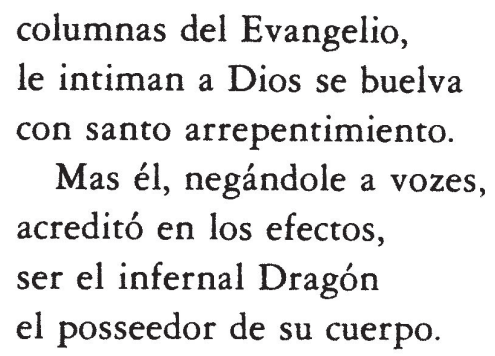

Es, pues, la impiedad de Manuel Calderas (su rebeldía hacia las leyes humanas y divinas, sus blasfemias, oprobios y denuestos contra el juez «Assesor» y contra el «Juez de vivos y muertos») la que lo convierte en protagonista de la poesía de cordel y lo que más despierta la admiración del público. Como en las populares «aljabas» de romances usadas por los misioneros en su misión apostólica, el diablo transforma el romance en campo de una disputa teológica: auxiliadora potencia mitológica o «infernal Dragón» de la imaginería cristiana.

Pero los «estremos» de Manuel Calderas no cesan en este punto. Falta ver la vigilia del reo encapillado: su esperanza deshecha. Falta el instante supremo de la muerte, la «leve flor» que troncha el «corte de una pluma». Falta, en suma, el instante del arrepentimiento (del «santo arrepentimiento»):

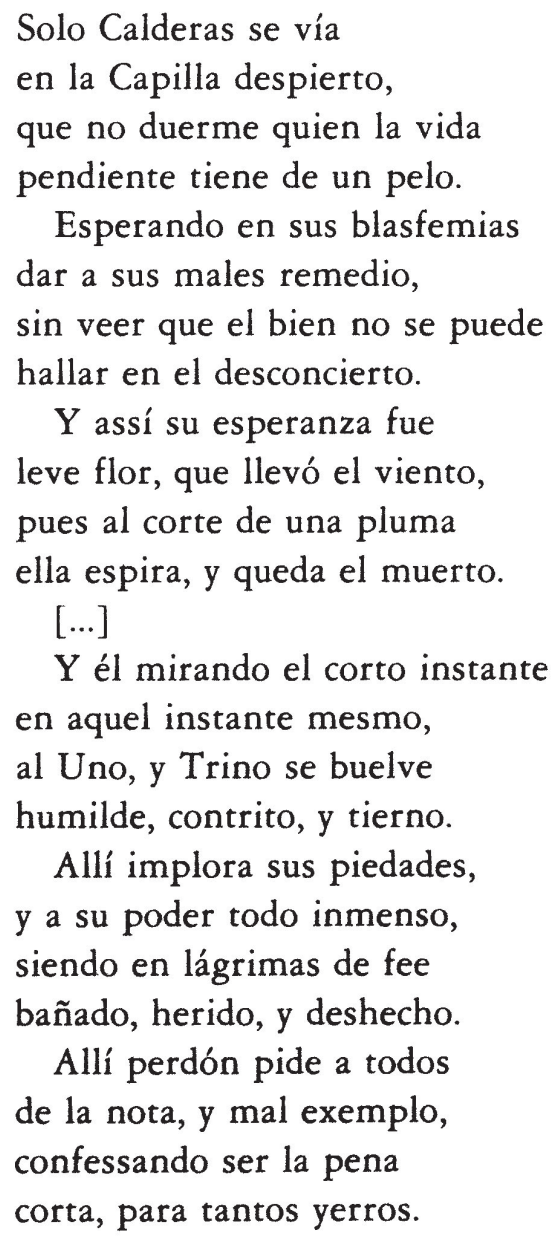


La piedad forma la contraparte del terror ejercido por el pliego suelto: piedad de Dios implorada por el delincuente, piadosa retractación del reo, cristiana piedad del público ante el escarmiento. La impiedad de la víctima glorifica al ajusticiado, pero también consagra su arrepentimiento: «si el condenado se mostraba arrepentido, pidiendo perdón a Dios y a los hombres por sus crímenes, se le veía purificado: moría, a su manera, como un santo» ${ }^{61}$.

Transformado en una suerte de falso predicador callejero, el romancista es intérprete de la justicia oficial e intérprete, asimismo, de la piadosa religiosidad del pueblo. Se especializa en un género de «discurso apócrifo» (para emplear otro término de Foucault) que proclama las penas del ajusticiado:

Por cuya Alma aquí se pide

a Dios rueguen; pues el Cuerpo

por piedad del Juez, oy goza

de la immunidad del Templo.

9. Vamos a reencontrar a Patricio López, luego de un largo intervalo, escribiendo un romance con motivo del «tránsito» por la ciudad de Xalapa del virrey de la Nueva España, en 1740. Se trata nada menos que del Mercurio Indiano ${ }^{62}$, romance histórico inédito del cacique zapoteco al que acompañan otros cuatro documentos: un «Proemio» y una dedicatoria diri-

${ }^{61}$ Michel Foucault, op. cit., pp. 71-72.

62 El manuscrito del Mercurio Indiano fue descubierto por la doctora Beatriz Mariscal en la Biblioteca Bancroft. Utilizo, provisionalmente, para mi trabajo, la transcripción elaborada por Araceli Esquer, Ana Rosa González Matute y Liliana Irene Weinberg en el Seminario de Edición de Textos a cargo de la doctora Mariscal. El título completo del Mercurio Indiano es el siguiente: «El Mercurio Indiano, que en lo suscinto de un Romanze da noticias del Govierno Político y Militar que tubieron los Indios de este Orbe en su Gentilismo, los Encuentros, Batallas y tratados de paz que interbinieron entre el emperador mexicano y el rey de los zapotecos de Oaxaca, y la oposición que éste siempre le hizo; sin que jamás le hubiese podido sojuzgar por el valor y disciplina de los suios, hasta que con la entrada de los españoles, de motu proprio se sometieron a la obediencia real sin haver sido nunca conquistados. Da noticia assí mismo del Estado en que oy se hallan los Indios con otras cosas que se traen y apuntan. // Que al transitar por Xalapa para esta Corte el Excelentíssimo Don Pedro de Castro y Figueroa Duque de la Conquista del Consejo de Su Magestad Virrey, Governador y Capitán General de esta Nueba España y Presidente de la Audiencia Real y Chanzillería que en ella reside le consagró // Patricio Antonio López Cazique de la nación Zapoteca en los Valles de Oaxaca e Intérprete General del Apostólico y Real Tribunal de Cruzada y Superior Gobierno desta Nueva España.» 
gida al virrey, Conde de la Conquista; la transcripción de una carta relativa a la nobleza de la sangre indígena y a sus «mesclas» con la aristocracia española; una cédula real que reconoce los méritos y calidad de los indios; una apología trunca de los indios, fechada, ya no en julio de 1740 , como el romance, sino en febrero de 1754.

Del título del manuscrito se deduce una noticia importante, no tanto para la biografía de López como para la cabal comprensión de su romance. La firma habitual del romancista, en efecto, añade al de cacique el «honorífico título» de intérprete oficial de la Real Audiencia: «Patricio Antonio López Cazique de la nación Zapoteca en los Valles de Oaxaca e Intérprete General del Apostólico y Real Tribunal de Cruzada y Superior Gobierno desta Nueva España.»

El título incluye también un detallado argumento del Mercurio Indiano:

El Mercurio Indiano, que en lo suscinto de un Romanze da noticias del Govierno Político y Militar que tubieron los Indios de este Orbe en su Gentilismo, los Encuentros, Batallas y tratados de paz que interbinieron entre el emperador mexicano y el rey de los zapotecos de Oaxaca, y la oposición que éste siempre le izo; sin que jamás le hubiese podido sojuzgar por el valor y disciplina de los suios, hasta que con la entrada de los españoles, de motu proprio se sometieron a la obediencia real sin haver sido nunca conquistados. Da noticia assí mismo del Estado en que oy se hallan los Indios con otras cosas que se traen y apuntan.

Como los viejos romances «historiales», el Mercurio Indiano versifica la crónica de los señores zapotecos (antepasados de Patricio López). Es un romance mestizo que narra una historia indígena «en lo suscinto de un Romanze» español, y que se debe, él mismo, a la pluma de un olvidado señor indígena.

Pero el romance se vincula también con una circunstancia histórica precisa: el nacimiento de la prensa periódica ( $\mathrm{y}$ a través de ella, con el romance «vulgar»). Su título mismo alude a la naturaleza seudo-periodística del poema, «Mercurio Indiano», y a su carácter noticioso y de actualidad: «que en lo suscinto de un Romanze da noticias...»; «da noticia assí mismo del Estado en que oy se hallan los Indios con otras cosas que se traen y apuntan».

Último avatar del romance mestizo, el Mercurio Indiano conjuga esa moderna vertiente informativa del Romancero que es el romance vulgar con la crónica en verso de sucesos históricos y legendarios. El resultado de esa mixtura es un género radicalmente nuevo de la poesía novohispana: el romance apologético. 
Patricio López introduce su romance con una copla típica del romancero vulgar, aunque sobreponiendo a la de juglar su calidad de «yntérprete»:

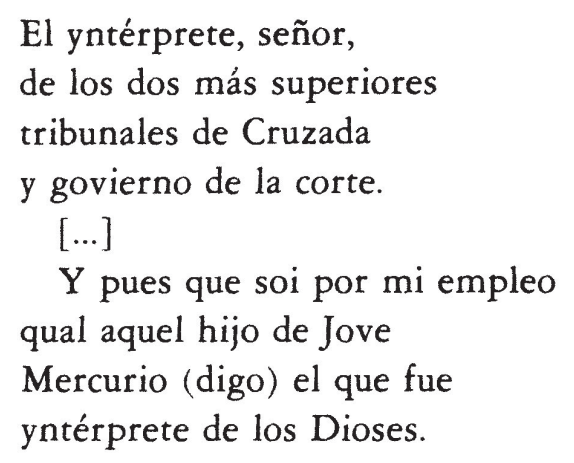

Es, precisamente, su calidad de intéprete la que autoriza a López para «copiar» ante el virrey «una parte» de las «rústicas mansiones» de los indios. El juglar se presenta, así, ante su público como un intermediario de los dioses, como un moderno rapsoda, como un mediador de mundos, lenguas y culturas.

No voy a reseñar, aquí, las noticias políticas y militares que brinda López acerca del «gentilismo» de los indios. Baste decir que el romancista pone el énfasis en el «concierto y orden» de su gobierno, «sin que les obste», como argumenta don Patricio, «la barbaridad que aora / se les arguie y supone».

Mayor atención merece la descripción de los tres «estados» en que solían dividirse las sociedades indígenas. Como en su numeración de los funcionarios indígenas prehispánicos, López traduce a términos europeos (y latinos: «juezes» y «prectores», ediles y «questores», «fundictores» y «caduciatores») los componentes de la jerarquía social indígena, comenzando por los caciques:

\author{
Havía entre ellos tres estados \\ de gentes con el agnomen \\ de Pili theubtli Maxebual \\ como en los demás de este orbe. \\ A los primeros, oy llaman \\ caziques que corresponde \\ en castellano hijodalgo \\ o duque, marqués, o conde.
}

Los «theuhtles» o «principales» son como los «senadores» del consejo del rey, que gobiernan las «repúblicas» de los indios. En cuanto a los macehuales, son «basallos» del rey sujetos al «feudo» de los caciques y doblemente sujetos a las «exacciones» (o al «pecho doble») del rey y sus otros señores: 


$$
\begin{aligned}
& \text { Mazeual eran los otros } \\
& \text { de la tercer clase y orden } \\
& \text { que es lo mismo que villanos } \\
& \text { gente de aldea o labradores. } \\
& \text { Aquestos oy, sirven tanto } \\
& \text { como aquel tiempo donde } \\
& \text { del reinado malo, o bueno } \\
& \text { sufrían el peso y el golpe. }
\end{aligned}
$$

Como lo acredita la experiencia de López en los tribunales, los indios son «cortos y bergonzosos» en sus pretensiones, sin que se les oiga lamentarse nunca cuando son rechazadas por los jueces. Viven «tan hallados en desdichas» que no los aflige opresión alguna ni confían en los bienes que se les ofrecen.

Don Patricio presta su voz a los «agrabios» callados en los tribunales:

Los agrabios que les hazen aunque el valor más les sobre temiendo del juez la saña callan, disimulan, oyen.

La relación del estado actual de los indios le sirve al romancista de pretexto para realzar la figura de los caciques, a quienes presenta como "protectores» y guardianes de los indios. Reincidiendo en la metáfora empleada en uno de sus romances de pliego suelto (la metáfora de los «rediles» y los «bellones»), López alude a los títulos tantas veces perdidos por esos caciques:

Los caziques que en sus pueblos suelen ser sus protectores se veen en continua guerra como el mastín con los leones.

Porque los que exquilman de estos rediles tantos bellones los atierran porque vivan solos, y assí los destrozen.

Algunos de ellos en estos pueblos tienen posesiones de tierras de quienes son caziques y no señores.

Otros no desfructan más del título, sólo el nombre porque al nacer en sus casas los hizo el cielo menores. 
Patricio López es, probablemente, uno de esos caciques sin más título que su propio nombre: sin posesiones territoriales; nacido en su casa y víctima, en cierto modo, de una injusticia; huérfano de sus privilegios ancestrales. Lo importante, en todo caso, es que esa calidad de «menor» no lo exime de su pesada carga social y cultural, depositada ahora en su función de intérprete.

Finalmente, el romancista se extiende en un hermoso y sencillo elogio de la tierra natal, nostálgicamente evocada luego de relatar la muerte del «ymperio» zapoteco. Patricio López, «Cazique Zapoteco de uno de los Valles de Antequera» (como acreditaba la firma de su primer romance), describe los ríos y los campos, el aire y las poblaciones de los tres valles de Oaxaca.

También aquí funge López como un auténtico «secretario de lenguas», al comenzar su evocación con una curiosa alusión al origen de la palabra «Oaxaca»:

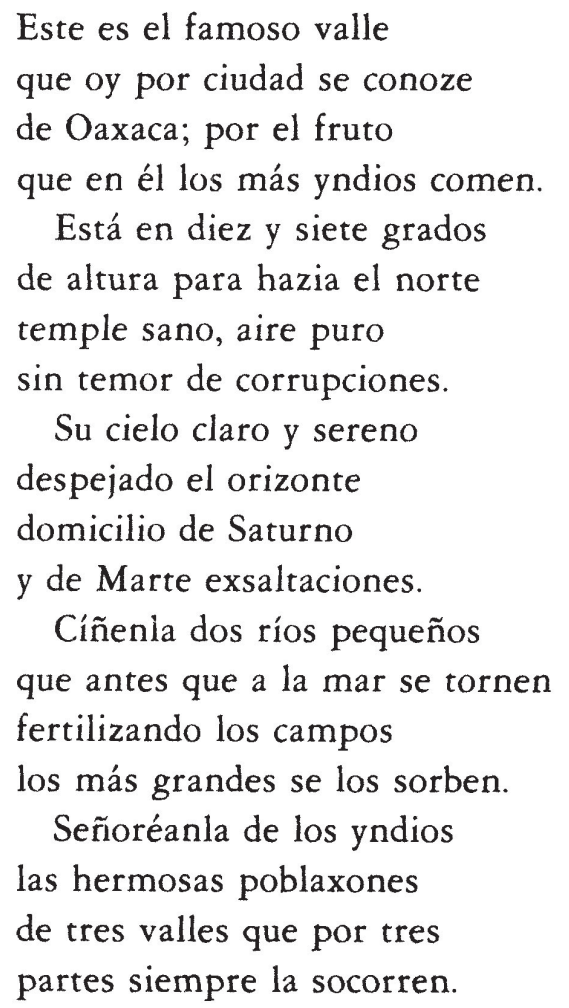

El Mercurio Indiano es, en su conjunto, un romance destinado al virrey en nombre de los indios de la Nueva España. La elección del metro, como veremos, tiene mucho que ver con los individuos sobre los que llama la atención el romance: aquellos a los cuales pretende prestarles voz y que forman, en definitiva, su público o su posible público. López se siente autorizado para asumir la representación de los indios: y lo que autoriza, en suma, su emisión (lo que delimita y construye su autoría sobre el silencio 
y las voces de la Babel indiana) es su triple condición de cacique que hereda el legado de una tradición; de intérprete acreditado en los juzgados de indios; de romancista versado en el estilo y las técnicas tradicionales del romancero vulgar.

$\mathrm{Y}$ don Patricio despide su romance con una técnica propia del ciego romancista, la peculiar «despedida» que canta el nombre y los «títulos» del poeta:

\author{
Vivid porque a buestro abrigo \\ a más asunto se engolfe \\ de Vuestra Excelencia el yntérprete \\ Don Patricio Antonio López.
}

10. El «Proemio» del Mercurio Indiano constituye, en rigor, una primorosa apología del intérprete, la reliquia de una tradición cultural casi subterránea que vinculó el romancero popular novohispano con la herencia indígena, y que hace posible afirmar: en la Nueva España, el poeta vulgar es intérprete.

Ya la dedicatoria destinada al virrey había puesto el énfasis en la forma poética elegida por Patricio López: el romance, «este pobre son tan claro como el agua por el estilo en que ba». Veinte años después de escrito su primer romance, la «poética» del romancista no ha variado significativamente, con su énfasis en la claridad, llaneza, simplicidad, brevedad y veracidad del romance.

«Nacido y criado entre los Indios», López reclama, en el «Proemio», el derecho que su ascendencia le da para escribir la historia. «Y quando caso negado, que no tiene assí, para ser author y ser creído en lo que trato en este papel, me basta el ser intérprete», escribe don Patricio, «instructor de las políticas costumbres de los Indios, celador y defensor de ellos en las injurias que se les hazen» (el subrayado es mío).

Ser intérprete implica cumplir con una serie de requerimientos, nada comunes por cierto: «conozida inteligencia, capazidad, virtud y nobleza; que traten verdad y guarden secreto como secretarios que son de lenguas».

$\mathrm{Y}$ es que el juez mismo depende, en sus fallos, del intérprete, de este «secretario de lenguas» a cuyo juicio tiene que atenerse, siempre, «en las interpretaciones que hazen de los procesos e ynstrumentos jurídicos de los Indios, o en las confesiones que les toman quando se hazen reos, por donde se condenan o se absuelven, en cualquier tribunal Inferior o Superior». 
En el intérprete descansa, hasta cierto punto, la posibilidad de absolver (y no ya sólo de condenar) a los indios. Así subvierte Patricio López el ámbito procesal en el que arraigaban sus tres romances de pliego suelto.

Sigue, luego, un bello elogio lingüístico e histórico de los intérpretes, cuya función traduce una inequívoca voluntad de universalidad: «a éstos llaman los mexicanos nabuatlatotin; los otomíes, nañaqueña; el zapoteco, guinibuichi; el mistheco, yiacandan; los venecianos, bailo, y los turcos, drogomanes».

«Uno vale por tantos hombres quantas lenguas sabe», escribe don $\mathrm{Pa}$ tricio. De ahí el privilegio concedido, en cualquier sociedad civilizada, a los intérpretes (privilegio que es, al mismo tiempo, un derecho que pueden reivindicar los súbditos): «entre los medos no se permitía hablar si no era por intérprete»; ningunas gentes sujetas al Imperio Romano, fueran griegos, cartagineses o españoles, podían hablar en el Senado «si no era por yntérpretes».

No se trata, obviamente, de una limitada reivindicación personal, y menos de una ostentación erudita. El intérprete presta su voz a los que no la tienen (aunque ésta no sea más que una figura retórica); reclama un derecho a hablar y ser escuchado, a universalizarse y adentrarse en sí mismo. Su voz es vehículo de otras voces: es la figura muda de lo que no se comprende.

El título mismo del poema, de acuerdo con el «Proemio», es una metáfora del intérprete (aunque no fuera sino porque yuxtapone dos tradiciones incomunicadas, grecolatina e indígena; aunque no hiciera más que revelar, tras la figura hermética del dios latino, los antiguos misterios y secretos de las lenguas):

Y siendo Mercurio no sólo intérprete embaxador, sino también el proprio dios de la eloquencia [López se apoya aquí en la cita de una autoridad latina], se le adapta bien esta obrilla por tres razones: lo primero, por ser parto de un intérprete; lo segundo, por embolberse en ella la embaxada que hago por los indios en el parabién que en sus nombres doi a Su Excelencia a su feliz arribo a este reino; y lo tercero, porque haviéndose presentado en Xalapa tránsito para la Corte de México, le acompañe en las fatigas del camino.

En cuanto al «estilo humilde en que va este Romanze», Patricio López vuelve a justificarlo con argumentos similares, cuando no idénticos, a los defendidos en la época de sus pliegos sueltos: la "escasés de ingenios» de sus lectores, «y la poca cultura que los más tienen de estudiosas erudicciones».

Lo que se revela es la identidad de esos lectores reales o imaginarios, y el reflejo oblicuo que de ellos destellaba en los pliegos sueltos. «No lo estrañes», dice López aludiendo a su estilo; «que hablando yo de las cosas 
del país y con los Indios y Mestizos mis compatriotas, es preciso baia en la forma que está». Y por si quedaran dudas: "porque para ellos lo escriví $y$ con ellos bablo, y no con los censores y desafectos de las cosas de los indios».

11. En su Idea de una Nueva Historia General de la América Septentrional, publicada en 1746, Lorenzo Boturini habla de los Cantares indígenas como de «unas sutílísimas fábulas tejidas con elevadas metáforas y alegorías» ${ }^{63}$. "Ni hay lengua», añade el caballero, "que en lo cortesano, en lo pulido, en lo tierno y en lo realzado de sus metáforas se pueda igualar a ésta [a la lengua nabuatl], como que fue labrada a golpes de poesía en el decurso de las dos edades». Y ejemplifica con el siguiente caso que dice haber sucedido en Texcoco:

Había un cierto emperador condenado a muerte a un vasallo suyo por delito correspondiente. Intimósele la fatal sentencia; y el reo, que era insigne poeta, en el poco tiempo que le quedó de vida compuso un cantar de despedida tan dulce $\mathrm{y}$ vestido de afectos tan vivos, que resolvieron los cantores de palacio [...] canrárselo al monarca con disimulo, quien no pudo menos de apiadarse del delincuente y perdonarle la vida, que es caso raro en las historias aculhuas, donde no se hallan sino ejemplares de la más severa justicia ${ }^{64}$.

Noble antecedente, por cierto, de las «coplas de ajusticiados» de Patricio López. Pero lo que quiero consignar aquí, a modo de apéndice de este trabajo, es el vínculo que une a nuestro romancista con el famoso historiador italiano.

¿Existió algún vínculo personal entre Patricio López y el caballero Lorenzo Boturini Benaduci? No hay ninguna huella de una amistad entre ellos, ni siquiera referencias de un contacto lejano. Llegado a México en marzo de 1736, Boturini fue expulsado siete años más tarde, en octubre de 1743. En ese lapso, el italiano reunió la más importante colección de documentos indígenas que conoció la Colonia, sin colaboración aparente del intérprete Patricio López.

63 Lorenzo Boturini BenaducI, Idea de una Nueva Historia General de la América Septentrional (México: Porrúa, 1986), p. 72. Las ideas de Boturini sobre la poesía indígena se reúnen en el capítulo titulado «De los nudos y cantares así históricos como poéticos», Ibid., pp. 71-77. La interpretación «metafórica» y «alegórica» de Boturini gozaría de gran fama entre los intérpretes de la Nueva España. (La Idea entera del caballero italiano, cuya fuente mitológica más importante es Ovidio, puede ser leída al modo de unas barroquizantes «Metamorfosis Indianas».)

64 Ibid., p. 76. 
Su fuente de inspiración fue la devastadora epidemia de matlazábuatl que despobló el país en 1737 (y en cuyo horizonte debemos situar la última obra de López). «La misma historia de la gentilidad que estaba por expirar», escribe Boturini, «clamaba por un sujeto que la sacase del túmulo del olvido» ${ }^{65}$.

Unos meses después de la expulsión de Boturini, en auto fechado «a dos días del mes de abril de mil setecientos cuarenta y cinco años», don Patricio recibía el encargo de formar el catálogo de la colección de «papeles, mapas y caracteres» del caballero italiano ${ }^{66}$. He aquí la causa de la elección de López:

Don Patricio Antonio López, intérprete general en esta Audiencia y Superior Gobierno, es persona de idoneidad, práctico y muy inteligente por su profesión en el idioma mexicano y en los mapas y caracteres de que antiguamente usaban los naturales de estos reinos.

Otro auto, fechado en 9 de abril, da cuenta del inicio de su tarea, que vale la pena seguir paso a paso a pesar de su aparente insignificancia:

Abierto el almario que está en dicha real caja, en la pieza que llaman el Libro Común $[\ldots]$, se le entregaron todos los mapas, caracteres, pinturas, libros y demás papeles $[\ldots]$, y separados y amarrados como se pusieron entonces, los pasó dicho intérprete a su casa.

Un informe dirigido al virrey, en 5 de julio, reseña los procedimientos seguidos hasta entonces y se refiere al inventario con evidente impaciencia:

Y en ello ha estado trabajando; y de mi orden, para su conclusión, se le ha instado por el escribano de la Guerra fenezca las dilgencias, que por lo voluminoso de ellas no ha podido concluir en todo este tiempo [...]. [Y añade:] Requerido dicho don Patricio, expresó tener ejecutado el reconocimiento, y para formalizarlo y ponerlo en limpio, me pidió el término de diez días que le he concedido.

${ }^{4}$ Ibid., p. 5. La vinculación del proyecto de Boturini con la gran epidemia de 1737 (que causó más de cuarenta mil muertes en México y cerca de cincuenta y cuatro mil en Puebla) es expuesta por Miguel León Portilla en su «Estudio preliminar» al libro de Boturini. Ibid., pp. XV-XVI.

66 La colección de autos e informes citados en este párrafo puede encontrarse en José Torre Revello, «Documentos relativos a don Lorenzo Boturini Benaduci», Boletín del Archivo General de la Nación, 1. época, 7 (1-4) 1936), pp. 5-45, 229-255, 362-401 y $565-595$. 
Entregado el inventario el día 15 de julio, conforme a lo acordado en el informe anterior, restaba sólo devolver la colección a su viejo «almario»:

Y partida por partida se fue llamando y entregando dicho intérprete, y lo fue recibiendo y reconociendo según sus títulos y foliajes el dicho don Félix de Sandoval, e introduciendo en el almario referido.

Pero no sin contratiempo. Al término de su revisión, don Patricio descubre la ausencia de un libro de a octavo, sin valor histórico o literario alguno:

El cual dijo el dicho intérprete haberlo tenido presente en el citado resumen y reconocimiento que hizo, y tocar al inventario octavo al número quince; y que puede haberse extraído por alguno de los indios cargadores que condujeron dichos papeles, libros y mapas.

Al final de este episodio mínimo de la transmisión tradicional (y vuelto el librito a su ámbito natural de existencia), López paga el pato, «obligándose a hacer la diligencia de su solicitud en librería donde se venden libros» ${ }^{67}$.

Pero pasemos a España para cerrar este capítulo. Apoyándose en sus amigos de la Academia de la Historia (fundada en 1763), Boturini hizo todo lo posible para recuperar su archivo y regresar a trabajaar a América. En consulta fechada en 25 de mayo de 1746, el mismísimo Consejo de Indias elevó una petición al monarca respaldando las demandas de Boturini. Pero la consulta contenía una propuesta más interesante aún: fundar una Academia de la Historia en México, compuesta por individuos capaces de colaborar con Boturini en la redacción de su proyectada (y nunca terminada) Historia General de la América Septentrional:

Añadiendo sólo [se lee al cabo de dicha consulta] que tiene por muy conveniente el que, si vuestra majestad fuese servido de mandar establecer y fundar en México la enunciada Academia de Historia de la América Septentrional, sea uno de los primeros académicos y fundadores de ella el referido intérprete don Patricio Antonio López, respecto de concurrir en él todos los requisitos para adelantar más

67 El Inventario de Patricio López se conserva en la Biblioteca del Museo Nacional de Antropología e Historia. Consta de 71 hojas manuscritas e incluye el romance indígena de Fernando de Alva Ixtlilxóchitl («traducción» de un cantar de Nezahualcoyotl) que comenté al principio de este trabajo. Cf. Patricio Antonio LOPEZ, «Inventario de los documentos recogidos a don Lorenzo Boturini por orden del gobierno virreinal», Anuales del Museo Nacional de Arqueología, Historia y Etnografía, 4." época, 3 (1) (1925), pp. 1 15 . 
que otros en el acierto y desempeño de un tan difícil asunto, para lo cual le conduciría mucho el conocimiento y examen que ha hecho de los libros, mapas, pinturas y papeles de don Lorenzo Boturini.

Nunca el ideal de Giambattista Vico (que era el de Boturini) hubiera tenido una consumación más plena que si este proyecto hubiera llegado a realizarse ${ }^{68}$.

\author{
ENRIQUE FLORES \\ Instituto de Investigaciones Filológicas. \\ UNAM. México
}

El trabajo titulado «Patricio Antonio López, indio romancista» representa una aproximación a lo que fue el romancero popular novohispano del siglo XVIII y, más generalmente, a la pervivencia del Romancero Vulgar en tierras americanas. Al mismo tiempo, este trabajo intenta resaltar la figura de Patricio López: autor de romances de bandoleros, intérprete general de la Real Audiencia e involuntario colaborador del proyecto del caballero Lorenzo Boturini.

The work entitled «Patricio Antonio López, indio romancista» is an approach to the Eighteenth century popular Novohispanic balladry, and in a more general sense, to the survival of the Romancero Vulgar in Spanish America. But it is also an attempt to point at the character of Patricio López: author of bandit's ballads, general interpreter of the Real Audiencia and unwilling collaborator in gentleman Lorenzo Buturini's project.

68 El monarca aprobó los dos primeros puntos de la propuesta de sus consejeros: nombró a Boturini "Cronista en Indias» (cargo que nunca llegó a ejercer realmente) y autorizó su regreso a la Nueva España. Por lo que al tercer punto se refiere, Felipe $V$ tuvo «por cosa irregular» la creación de una Academia de la Historia en México (LEÓNPORTILLA, op. cit., pP. XXVII-XXVIII). 